\title{
КОНТЕКСТНАЯ МОДЕРАЦИЯ АНТИИММИГРАНТСКИХ МОТИВАЦИЙ К ГОЛОСОВАНИЮ ЗА РАДИКАЛЬНЫЕ ПРАВЫЕ ПАРТИИ В ЕВРОПЕ
}

\author{
В.В. Сафронов
}

\author{
(vsafronov@list.ru) \\ Социологический институт РАН - филиал ФНИСЦ РАН, \\ Санкт-Петербург, Россия
}

Цитирование: Сафронов В.В. Контекстная модерация антииммигрантских мотиваций к голосованию за радикальные правые партии в Европе // Власть и элиты. 2021. Т. 8, № 2. С. 134-188.

DOI: https://doi.org/10.31119/pe.2021.8.2.6

\begin{abstract}
Аннотация. Рассматриваются общественные условия в странах Европы, способствующие успехам на парламентских выборах радикальных правых партий (РПП). В предшествующих исследованиях, которые нередко приводят к рассогласованным результатам, недостаточно внимания уделялось теоретическому обоснованию и эмпирической проверке предположений, связанных с влиянием социетального контекста на зависимость между антииммигрантскими аттитюдами и электоральной поддержкой РПП. Анализ опросных данных Европейского сочиального исследования (ESS, последние раунды) и иелого ряда контекстуальных факторов, различающих страны Европы по состоянию экономики, иммигрантского населения, преступности, партийных систем и культуры, проводился статистическими методами двухуровневого логистического моделирования. Он показал, что негативное отношение опрошенных к иммиграции является важнейшей причиной их электоральной поддержки радикальных националистических партий. Эта зависимость особенно отчетливо проявляется в западных странах, но ее можно обнаружить и в Восточной Европе. Структурные, институциональнье и культурные факторы лищь очень
\end{abstract}


слабо связаны с неодинаковыми показателями успеха этих партий в изучавшихся странах. Наиболее отчетливая зависимость обнаруживается при рассмотрении партийных систем. Результаты показывают, что правым радикалам удается добиться успеха в том случае, когда их избирательные призывы получают легитимацию благодаря смещению в консервативно-националистическом направлении основной правой партии или партийной системь в иелом. Им удается привлечь больше избирателей также при высокой значимости в партийной системе соииокультурных проблем и сильной поляризации партийных позиций по этим проблемам. Целый ряд контекстуальных бакторов выступают модераторами зависимостей между антииммигрантскими убеждениями опрошенных и голосованием за РПП. Индивиды, придерживаюшиеся этих убеждений, отдают свои голоса радикальным партиям особенно охотно, когда в стране живет много иммигрантов или их число быстро растет. Еще одно важное условие - продвижение общества по траектории постиндустриального развития. Антииммигрантские мотивации голосования за националистические партии усиливаются с повышением экономического благосостояния, расширением сектора услуг, укреплением социального государства и при ценностном сдвиге в культуре от ориентаций на устранение тревоги к тичностному развитию.

Ключевые слова: радикальные правые партии, парламентские выборы, голосование, антииммигрантские убеждения, контекстуальные обиественные факторы, эффекты модерации, Европейское соииальное исследование (ESS Round 9).

\section{МАКРОКОНТЕКСТЫ ГОЛОСОВАНИЯ ЗА РАДИКАЛЬНЫЕ ПРАВЫЕ ПАРТИИ: СОСТОЯНИЕ ИССЛЕДОВАНИЙ}

Новые радикальные правые партии (РПП), появление которых стало заметным в Европе уже в 1980-е годы, продолжали закреплять в последующие десятилетия свои электоральные успехи на парламентских выборах, хотя случались и провалы. Сегодня они участвуют в политической жизни практически любой из стран Западной и Восточной Европы, составляя в некоторых из них серьезную конкуренцию ведущим левым и правым партиям и играя важную роль в формировании правительств. Их возрождение, как отмечает Й. Ридгрен, является «важнейшим изменением в политических системах демократических стран за последние три десятка лет» [Rydgren 2018: 1]. Отличительными чертами идеологии радикальных правых партий выступают этнический национализм (нативизм), авторитаризм (неприятие либеральной демо- 
кратии, защищающей права меньшинств) и популизм (разделение на коррумпированную политическую элиту и незапятнанный народ, требующий ее смещения) [Mudde 2007; Rydgren 2018: 1-6]. «Новые радикальные партии правого толка содержат в ядре этнонационалистическую ксенофобию и популизм против истеблишмента. В их политических платформах это идеологическое ядро встроено в общий социокультурный авторитаризм, для которого важны такие темы, как закон и порядок и ценность семьи» [Rydgren 2007: 242-243]. Самый важный общий знаменатель популистских правых партий - этнонациональное представление о гражданстве, предполагающее, что государство должно состоять исключительно из представителей определенной нации, а те, кто к ней не относятся, несут угрозу такой однородной нации-государству [Muis, Immerzeel 2017: 910]. Основная общественная проблема для РПП - иммиграция, поскольку приезжие, согласно их аргументам, представляют угрозу для этнонациональной идентичности, становятся главной причиной преступности, отсутствия в обществе безопасности, безработицы и предъявляют необоснованные претензии на социальные блага, что ведет к их истощению [Rydgren 2007: 244].

Многочисленные работы, образующие отдельное направление электоральных исследований, позволили в определенной степени объяснить причины растущей поддержки РПП у избирателей и определить общественные условия, способствующие голосованию за эти партии. Х-Г. Бетц отмечал в начале 1990-х годов, что радикальные правые популистские партии (представленные итальянской Северной лигой, Фламандским блоком в Бельгии, Австрийской партией свободы и немецкой партией Республиканцы) появляются в ответ на глубокие экономические, социальные и культурные трансформации, связанные c «переходом от индустриального капитализма социальных гарантий к постиндустриальному индивидуализированному капитализму» [Betz 1993: 665]. Постиндустриальное развитие, считает Г. Китшелт, - первое условие подъема правого партийного радикализма [Kitschelt, McGann 1995]. Общее теоретическое основание, служащее объяснению подъема популистских радикальных правых, пишет в недавнем обзоре К. Мудде, - «тезис о модернизации, выраженный главным образом в терминах глобализации в исследованиях Западной Европы <...> и трансформации в работах по Восточной Европе» [Mudde 2016: 8]. Эти процессы общественного изменения сопровождались появлением проигравших, особенно в нижних и менее образованных классах (но и среди некруп- 
ных собственников), а также мобилизацией заметой части общества, для которой неприемлемыми были либеральные сдвиги в культуре, и все расширяющимся притоком в Европу иммигрантов и беженцев из слаборазвитых стран с неевропейскими традициями, обостряющим конкуренцию за рабочие места и межкультурные конфликты. Все это вело к дальнейшему реструктурированию политического противостояния, которое в дополнение к традиционным темам, связанным с экономикой и благосостоянием, стало разворачиваться вокруг социокультурных проблем между радикальными правыми и (новыми) левыми партиями [Bornschier 2018; Golder 2016; Ignazi 1992; Inglehart 1977; 1990; 1997; Kitschelt, McGann 1995; Norris and Inglehart 2018].

Исследования, нацеленные на выявление демографических, социальных и аттитюдных характеристик избирателей РПП, действительно показывают, что среди них диспропорционально представлены нижние общественные классы, рабочие и низкоквалифицированные работники (и мелкие предприниматели), имеющие невысокое образование, мужчины и младшие возрастные категории, а также люди, обеспокоенные экзистенциальной безопасностью и разделяющие традиционно-консервативные ценности, однако важнейшее отличительное свойство этих избирателей - негативное отношение к иммиграции и антииммигрантские аттитюды. В сегодняшней оценке состояния дел Й. Ридгрен указывает, что «антииммигрантские настроения являются самостоятельной наиболее важной причиной того, почему избиратели поддерживают радикальных правых» [Rydgren 2018: 7]. Согласно метаанализу статей за два с лишним десятилетия, такая зависимость все же обнаруживается далеко не во всех работах [Stockemer, Lentz, Mayer 2018], однако последние исследования вновь подтверждает ее существование. Так, по данным опросов Европейского социального исследования (ESS, восемь раундов), антииммигрантские аттитюды - один из ключевых факторов голосования за крайние правые партии, причем успех этих партий зависит от мобилизации избирателей, которые как видят в иммиграции культурную угрозу, так и связывают ее с экономическими трудностями [Halikiopoulou, Vlandas 2020]. Правда, неприятие иммиграции - важное, но не единственное условие поддержки этих партий, около трети их электората относятся к иммигрантам без неприязни [Stockemer, Halikiopoulou, Vlandas 2020]. В странах Центральной и Восточной Европы популистские националистические партии тоже используют мобилизацию против этнических меньшинств, и если раньше 
это делалось по отношению к людям других национальностей, проживающих в стране, то в последнее время - против иммигрантов из неевропейских стран [Buštíková 2018]. Например, опросы в посткоммунистических странах (Болгарии, Латвии, Литве и Словакии) 2007 г. показали, что электорат крайних правых партий отличается сильной ксенофобией к этнической группе, оставшейся от бывшего имперского большинства [Stefanovic, Evans 2019]. Сравнение избирателей крайних правых партий в Западной и Центральной-Восточной Европе (по данным ESS 2004-2008) показало, что наиболее отчетливое расхождение проявлялось по признаку антииммигрантских аттитюдов - они гораздо сильнее влияли на голосование на Западе, хотя такая зависимость проявлялась и в других странах [Allen 2017]. По данным ESS 20142016 гг., антииммигрантские аттитюды - важнейшее средство различения избирателей крайних правых партий и других партийных семейств, хотя в Восточной Европе их влияние было намного слабее, чем в западных странах [Brils, Muis, Gaidyte 2020].

Исследования «спроса» - социально-демографических особенностей и аттитюдов избирателей РПП, указывающие на причины поддержки в обществе их идеологии, - имеют ограниченные объяснительные возможности. Согласно получившей общее признание точке зрения, полное объяснение «требует выхода за пределы модели спроса. Она не позволяет понять краткосрочные флуктуации внутри стран или большие различия между сходными в иных отношениях странами» [Muis and Immerzeel 2017: 912]. В 2000-е годы предпринимаются попытки ответить на вопрос, почему одни из радикальных правых партий добиваются успеха на выборах, а другие - нет, при этом в центре внимания оказываются не особенности электората, свидетельствующие о «спросе» на избирательном рынке, а факторы «предложения», характеризующие сами эти партии и общественные условия, в которых они действуют. В сравнительных исследованиях голосования за РПП анализировался целый ряд контекстуальных факторов, таких как острота безработицы, численность иммигрантов, масштабы преступности, развитость социального государства, особенности партийной системы и предвыборных идеологических позиций партий, и другие.

Так, экологический анализ электоральных намерений избирателей в шести западноевропейских странах (Бельгия, Дания, Западная Германия, Италия, Нидерланды и Франция, период - 1984-1993 гг.) свидетельствует, что экстремизму правого толка способствуют иммиграция 
и общественное недовольство политическим режимом, но не проблемы национальной экономики - при высокой безработице доля его сторонников сокращается [Knigge 1998]. По другим сведениям, безработица также ведет к снижению поддержки крайних правых - в условиях экономических трудностей, люди, вероятно, склонны полагаться на компетенцию в этих вопросах системных партий [Arzheimer, Carter 2006]. Согласно еще одним результатам, напротив, голосованию за крайние правые партии в Западной Европе способствует высокий уровень безработицы [Jackman and Volpert 1996]. Кроме того, отмечается, что такие партии были более успешными при высоком показателе уровня иммиграции, но и безработица имела значение, оказывая влияние во взаимодействии с этим показателем [Golder 2003]. По другому заключению не подтверждается зависимость между долей голосов в стране за радикальные правые партии и размерами иммигрантского сообщества [Norris 2005: 185].

Исследование в 16 странах Западной Европы (1994-1997) приводит к противоположному выводу - успехи крайних правых прямо зависели от доли среди населения людей, не имеющих гражданства в ЕС [Lubbers, Gijsberts, Scheepers 2002]. Однако предположение о межуровневой интеракции этого контекстуального фактора и индивидуальных аттитюдов к иммигрантам - повышении вероятности голосования за эти партии тех, кто негативно относится к приезжим, при большем их представительстве в стране - не получило подтверждения. Изучение парламентских выборов в землях Германии и Австрии (с 1960-х по 1994) и регионах Франции (1973-1993) приводит к противоречивым результатам: во Франции и Австрии «радикальные правые получали больше голосов в регионах, где безработица, иммиграция и неучастие в выборах были высокими. <...> Случай Германии, однако, вызывает сомнения в способности этих переменных предсказывать голосование за радикальных правых во всех странах» [Givens 2002: 155]. Только низкая явка во всех трех случаях была связана с голосованием за правых радикалов, так что условием их поддержки является, возможно, недовольство избирателей политикой основных партий. Согласно исследованию электоральных намерений и обусловливающих их индивидуальных и контекстуальных факторов [Kessler, Freeman 2005], в котором анализировались данные Евробарометров 1988, 1994, 1997 и 2000 гг., поддержку крайним правым партиям в Западной Европе (семь стран, где такие партии добивались успеха на парламентских выборах, а также 
расширенный набор из 15 стран) оказывают общественные группы, пострадавшие от экономических и политических изменений в постиндустриальную эпоху, и люди с антииммигрантскими настроениями, кроме того, эта поддержка зависит от политического, но не экономического контекста, повышаясь с ростом в стране иностранного населения, однако снижаясь при более высокой безработице.

Изучение влияния на голосование за радикальные правые партии глобализации и социального государства (эмпирический анализ выборов в 16 западноевропейских странах, проводившихся с 1981 по 1998 г.), продемонстрировало, что «международная интеграция, заметное усиление транснациональных потоков товаров, капитала и людей в последние десятилетия вносят вклад в электоральный успех новых крайних правых партий в Западной Европе», причем выраженность таких зависимостей становится менее отчетливой по мере все большей ориентации государства социальных гарантий на принципы универсальности [Swank, Betz 2003: 238]. Кроме того, было установлено поддерживающее воздействие на голосование за крайних правых деиндустриализации (по показателю снижения занятости в промышленности), которое также ослабевает при универсальном обеспечении государственной социальной защиты, а также политических факторов - пропорциональности избирательной системы, усиления на предшествующих выборах левых либертарианских партий и самих правых радикалов. Большие электоральные достижения конкурирующей с радикалами основной правой партии, напротив, препятствуют поддержке новых правых. Не подтверждаются соображения о воздействии экономических трудностей (низких темпов экономического роста, растущей безработицы и инфляции). Недавняя работа подкрепляет соображение о сокращении поддержки РПП вследствие снижения остроты конфликта с приезжими при щедрой компенсации государством трудностей, обусловленных невысоким общественным положением [Vlandas, Halikiopoulou 2021].

Экологический анализ различий голосования в странах Западной Европе на парламентских выборах 1989-1999 гг. за 13 антииммигрантских партий [Van der Brug, Fennema, Tillie 2005] не подтверждает социоструктурную модель, связывающую их успех с высокой иммиграцией, проблемами в экономике и неудовлетворенностью политической системой. Их электоральный потенциал зависит от «существования заметной группы избирателей на правом фланге, оценивающих партию 
преимущественно по ее идеологической позиции» [р. 559], а его реализации на выборах способствует благоприятная «структура электоральных возможностей».

Тем не менее фактор иммиграции, скорее всего, имеет значение, побуждая к голосованию за крайние правые партии [Arzheimer 2009]. Обобщая в недавнем обзоре выявленные факты, К. Арцхеймер пишет, что «наличие или отсутствие иммигрантов и иммиграции, частота и характер контактов между иммигрантами и коренным населением и то, каково отношение к иммиграции других политических игроков и медиа, являются основными факторами, вносящими вклад в поддержку радикальных правых» [Arzheimer 2018: 159]. Обеспокоенность в обществе проблемой иммиграции может усиливать влияние переменных индивидуального уровня. Так, было установлено, что воздействие национальной идентификации в странах Европы на голосование за эти партии становится более выраженным, когда общественное мнение выражает большую озабоченность этнической угрозой [Lubbers, Coenders 2017].

Следует отметить, что исследование на субнациональном уровне сопоставление региональных результатов выборов в национальные и европейский парламенты - говорит об отчетливом влиянии на голосование за правых популистов и безработицы, и иммиграции, и неравенства доходов, причем эффекты экономической небезопасности были более выраженными в регионах, которые испытывали быстрый приток иммигрантов [Georgiadou, Rori, Roumanias 2018].

Важное место в призывах РПП занимает проблема девиантности «главным вопросом авторитарной программы популистских правых является борьба с преступностью» [Mudde, 2007: 146]. Неоднозначные результаты исследований фактора иммиграции привели к предположению о том, что он становится важным для голосования за РПП, если иммиграция связывается с ростом преступности - для этих партий характерна электоральная стратегия, подразумевающая криминализацию иммиграции. Анализ выборов в парламент Нидерландов 2002 г., в котором рассматривались индивидуальные переменные, контекстуальные детерминанты (характеризующие соседские сообщества) и модерации между ними, действительно продемонстрировал, что голосование за националистическую партию (Пим Фортёйн Лист, LPF) было выше при высоком уровне иммиграции, но только среди избирателей, обеспокоенных преступностью, а также при значительной преступно- 
сти - среди тех, кто выступал за политику ассимиляции иммигрантов, кроме того, росту голосов способствовало признание индивидом необходимости ужесточения одновременно и иммиграционной политики, и борьбы с преступностью [Dinas, van Spanje 2011]. Рост в Западной Европе радикальных правых партий в последние десятилетия происходил одновременно с беспрецедентным подъемом преступности. В связи с этим высказывалось соображение, что радикальные правые партии «присваивают» проблему преступности, с которой не удается справиться основным партиям, и апеллируют к избирателям, испытывающим чувство физической и социальной незащищенности вследствие этого подъема. Анализ национальных парламентских выборов в 18 западноевропейских странах с 1970 до 2005 г. действительно показывает, что популистские правые партии получают большую поддержку на выборах при повышении уровня преступности самого по себе, а также в том случае, когда он сочетается с иммиграцией [Smith 2010].

Наряду с изучением структурных факторов общественного контекста, много внимания уделялось исследованию политических возможностей - некоторые результаты уже упоминались выше. Особенности электоральных институтов и партийных систем, согласно анализу парламентских выборов в Западной Европе (16 стран, с 1970 по 1990 г.), влияют на поддержку крайних правых партий - повышение электоральных порогов представительства препятствует их поддержке, а многопартийность ей, напротив, способствует, благоприятным для этих партий условием является и высокая безработица [Jackman, Volpert 1996]. Проверка этих результатов, выполненная на тех же эмпирических данных, однако, не подтвердила заключения о роли электоральных институтов и поставила под сомнение утверждение о стимулировании голосования за крайние правые партии при повышении уровня безработицы: анализ свидетельствует, что увеличение числа безработных повышает избирательные результаты только популистских, но не неофашистских, партий, причем это происходит лишь при значительной доле в стране иностранцев [Golder 2003: 534]. По заключению других исследований, размер избирательных округов и электоральная формула, как и ограничения в доступе к участию в выборах, СМИ, партийному финансированию, не связаны с поддержкой правых экстремистских партий [Carter 2002; 2005: 148-155]. Это подтверждается анализом П. Норрис, также не обнаружившим «психологического стимулирования» к голосованию за РПП в избирательных системах с пропорцио- 
нальным представительством и низкими порогами [Norris 2005: 124]. Но можно найти подтверждения теоретически предполагаемой зависимости, в соответствие с которой благоприятные условия для этих партий складываются в «консенсусных демократиях», в отличие от мажоритарных систем, правда, такое влияние пропорционального представительства было неустойчивым, исчезая при изменении статистической модели [Van der Brug, Fennema, Tillie 2005]. Сообщалось и о противоположных ожидаемым взаимосвязях - диспропорциональность избирательной системы способствовала росту поддержки крайних правых партий [Arzheimer, Carter 2006]. К. Арцхеймер полагает, что при должном контроле «децентрализация и диспропорциональность избирательной системы не оказывают статистически значимого влияния на поддержку ER (крайних правых - BC)» [Arzheimer 2009: 269]. Воздействие политических институтов на поддержку правых экстремистов, по мнению Г. Китшелта, является незначительным, неоднозначные выводы отчасти обусловлены методологическими причинами, связанными с неадекватной оценкой институтов, но и «при прямом измерении институтов <...> исследования успеха радикальных правых партий приводят к противоречивым результатам» [Kitschelt 2007; 2018: 12].

Политические возможности связаны не только с электоральными институтами, но и с идеологическим позиционированием партий наличием для РПП пространства, оставшегося незанятым в конкурентных стратегиях ведущих игроков в партийной системе. Одно из существенных условий в Западной Европе для занятия крайними правыми ниши на электоральном рынке, по влиятельной теории Г. Китшелта, «основные партии экономических левых и правых, социальные демократы или социалисты, с одной стороны, и христианские демократы или консерваторы - с другой, движутся по пути стратегического сближения, сменяя друг друга в правительстве и/или вступая в правительственные коалиции» [Kitschelt, McGann 1995: 275]. Результаты одной из проверок показывают, что успеху крайних правых партий способствует пропорциональная избирательная система (больший размер избирательного округа), открывающая возможности для электорального выражения правых авторитарных требований, возникающих в постиндустриальных обществах с развитым социальным государством, но, вопреки теории, не сближение позиций основных партий [Veugelers, Magnan 2005]. Однако анализ выборов в Европе в 1990-е годы позволил установить, что доля голосов, отданных крайним правым, увеличива- 
ется, если основная правая партия занимает центристскую позицию, а не смещается к правому полюсу [Van der Brug, Fennema, Tillie 2005]. Е. Картер отмечает, что радикальная правая становится успешнее при сдвиге к центру системной правой партии, а также при сближении основных левых и правых партий [Carter 2005: Ch. 4]. Согласно еще одному исследованию, в котором контролировались переменные как индивидуального, так и контекстуального уровней, сближение между системными партиями, проявляющееся в формировании правительств «большой коалиции», повышает вероятность получения голосов правыми радикалами, однако, в противоречии с описанными выше результатами, очень жесткое отношение основных правых партий к проблеме иммиграции, их сдвиг вправо эту вероятность тоже повышают, поскольку легитимируют для избирателей заявления экстремистов [Arzheimer, Carter 2006]. В Восточной Европе одна из характерных особенностей радикальной правой мобилизации - склонность основных партий к радикализму правого толка, что создает терпимое окружение и легитимирует РПП [Bustikova 2018].

В других исследованиях такие зависимости с позицией системной правой партии или с относительным расположением основных партий не выявляются. Разность позиций радикалов и системной партии, которая к ним ближе всего в плане требуемых ограничений, не объясняет различий между странами в поддержке правых экстремистов [Lubbers, Gijsberts, and Scheepers 2002: 364-365]. Между различиями ведущих левых и правых партий и долей голосов за правых радикалов или полученных ими парламентских мест нет значимых корреляций [Norris 2005: 196]. Тем не менее недавний анализ по материалам экспертного опроса 20102011 гг, проводившегося в 25 странах Западной и Восточной Европы, стратегической дивергенции и конвергенции политических позиций радикальных правых и всех других партий по вопросам, поднимаемым правыми радикалами в идеологическом (иммиграция, национализм, закон и порядок) и стилевом (популизм, антиистэблишмент) измерениях, свидетельствует, что в идеологии к ним близки консервативные и христианско-демократические партии, а отличаются социалисты и зеленые, тогда как по стилю, наоборот, наблюдается сходство с левыми партиями и различия - с правыми, кроме того, важно отметить, что большую долю голосов РПП в западных странах получают при схожести их позиций с позициями конкурентов по вопросам иммиграции и ужесточения законов [Immerzeel, Lubbers, Coffé 2016]. 
Другой теоретический взгляд на зависимость голосования за радикалов от позиций основных партий предполагает, что стратегии этих партий могут быть направлены на изменение значимости и монополизации поднимаемых крайними правыми проблем (salience, issue ownership) [Meguid 2005]. Так, новая партия, занимающая крайнюю позицию по вопросам, остававшимся до этого вне поля политических дискуссий, сможет добиться успеха, если основная партия, не разделяющая такие взгляды, политизирует новое проблемное измерение, заявив о противоположной позиции в этих вопросах. Основная партия делает это для того, чтобы заставить другую системную партию - своего основного конкурента, позиция которого ближе к новой партии и у кого с ней есть общий бассейн избирателей, занять позицию по поднятой проблеме, что может привести к ее ослаблению вследствие разделения активистов и электората между старой и новой партиями. Эмпирический анализ голосования за зеленых и радикальные правые партии (17 стран Западной Европы, 1970-2000 гг.) показал, что их результаты действительно зависели от стратегий основных игроков по отношению к крайним партиям, особенно отчетливо повышаясь в том случае, когда оба системных конкурента избирали враждебные стратегии, способствующие, надо полагать, повышению значимости и монополизации новых проблем. Согласно другим результатам, хотя поддержка правых радикалов не связана с жесткостью позиции основной правой партии по соответствующим вопросам, на нее сильное влияние оказывала «значимость в избирательных программах действующих партий проблем, <поднимаемых> крайними правыми (иммиграция и национальная идентичность)» [Arzheimer 2009: 274]. В посткоммунистических демократиях успехи и неудачи РПП обусловлены динамикой их отношений с партиями, защищающими права меньшинств: повышение значимости проблем идентичности и увеличение партийной поляризации создают условия для мобилизации сторонников крайних националистов [Bustikova 2014]. Анализ правых радикалов в Венгрии, Польше и Словакии продемонстрировал, что идеологические границы между системными и радикальными партиями размыты, что создает для радикалов неблагоприятные конкурентные условия, но они могут добиться успеха, когда стратегии основных партий позволяют им монополизировать важные проблемы, имеющие общественный резонанс [Pytlas 2016]. Посткоммунистические преобразования в европейских странах, направленные на создание либеральных демократий и мультикультурных 
обществ, входящих в ЕС, вызывали ответную реакцию, проявившуюся в политизации проблемы меньшинств и поляризации политического спектра [Minkenberg, Kossack 2015].

Развитие теоретических представлений о влиянии «политического пространства» на успехи РПП было связано с выделением экономического и культурного измерений в идеологической конкуренции между партиями и анализом значимости и поляризации этих измерений для действующих партий. Как указывал Й. Ридгрен, «в последние несколько десятилетий значимость социокультурного разделения (cleavage) возросла за счет разделения экономического, в немалой степени вследствие политики идентичности и в том числе таких вопросов, как иммиграция, мультикультурализм и феминизм, а также окружающая среда $\langle\ldots\rangle$. Вполне вероятно, что это изменение привело к расширению политических возможностей для новых радикальных правых партий [Rydgren 2007: 253]. «Сближение традиционных партий в социально-экономическом измерении, - пишет Китшелт, - делает избирателей индифферентными к предлагаемым альтернативам и снижает их мотивацию к отслеживанию партийных позиций в этом измерении. А партийная поляризация по вопросам второго измерения (таким как иммиграция) снижает затраты на поиск различий между партиями в предлагаемой ими политике, что может объяснять поддержку новой партийной альтернативы» [Kitschelt 2018: 175]. Изучение в Западной Европе благоприятной для крайних правых партий структуры политических возможностей (17 стран, парламентские выборы 1980-2003 гг.), включая сходство позиций ведущих партий, позиционирование основной правой партии и поляризацию системы в экономическом и культурном измерениях партийной конкуренции (по данным Comparative Manifesto Project), продемонстрировало, что повышению доли голосов, получаемых крайними правыми в одних странах по отношению к другим, способствует снижение поляризации партийной системы по экономическим вопросам в сочетании с ее нарастанием по отношению к культурным проблемам, поднимаемым этими партиями [Spies, Franzmann 2011]. Результаты подтверждают также, что успех этих партий связан с большей долей среди населения выходцев из других стран. Исследование намерений представителей рабочего класса проголосовать за крайние правые партии вместо традиционных для них левых партий (13 стран Западной Европы с 1980 по 2002 г., по данным Евробарометров), в котором применялось двухуровневое моделирование с меж- 
уровневыми интеракциями, продемонстрировало, что переориентацию вызывает не смена политических предпочтений рабочих, а изменение партийной конкуренции, ведущее к снижению в партийной системе значимости экономических вопросов и экономической поляризации при противоположном тренде - росте значимости и поляризации для неэкономических вопросов, таких как иммиграция и закон и порядок [Spies 2013].

Таким образом, наш далеко не полный обзор исследований, учитывающий только наиболее влиятельные работы, свидетельствует, что результаты анализа контекстуальных факторов нередко оказываются рассогласованными и противоречивыми. Эта оценка подтверждается и метаанализом статей, посвященных структурным факторам голосования за радикальные правые партии в Западной Европе и опубликованных с 1990 по 2017 г. [Amengay, Stockemer 2019]. Согласно полученным результатам, теоретически предполагаемые зависимости для большинства (из более чем двадцати) изучавшихся переменных редко подтверждаются. В некоторых случаях, как, например, при изучении фактора иммиграции, выводы могут меняться при разной операционализации этого концепта. Так, предположение об увеличении доли голосов, полученных радикальными правыми партиями, при большем проценте среди населения иммигрантов из незападных стран подкрепляется в $53 \%$ из 41 регрессионных моделей, а когда показателем выступает численность ежегодно въезжающих в страну иммигрантов, зависимость выявляется только в $24 \%$ из 33 исследований. Более устойчивые, хотя и небезусловные, результаты удалось получить лишь для отдельных переменных, таких как уровень преступности (64 \% из 64 моделей) и размер избирательного округа (65 \% из 20) - с их увеличением растет электоральная поддержка радикальных правых партий, поскольку они выступают, как правило, за наведение порядка и ужесточение наказаний, а пропорциональные избирательные системы способствуют успеху небольших партий. Исследования электоральной конкуренции и идеологического позиционирования также не приводят к однозначным заключениям. В то же время в этой проблемной области важное продвижение было связано с разделением экономического и культурного измерения идеологического размежевания и измерением значимости и поляризации партийных систем в этих измерениях. Несмотря на многочисленные работы, посвященные контекстуальным факторам электоральной поддержки РПП, и использование в них 
не только экологического анализа, но и двухуровневого моделирования, в котором переменные индивидуального уровня рассматриваются совместно с факторами различий между странами, все еще недостаточно внимания уделяется взаимодействию между этими переменными и факторами. Обсуждая перспективы изучения крайних правых партий, М. Голдер отмечает: «Продвижение станет возможным при признании сущностного взаимодействия между факторами, действующими со стороны спроса и со стороны предложения» [Golder 2016: 493-494]. Отдельные работы, в которых анализировались такие интеракции, подкрепляют обоснованность этого утверждения, хотя теоретические ожидания в некоторых случаях, как мы видели, не подтверждаются. В настоящей работе предпринимается попытка дальнейшего изучения модерации контекстуальными структурными и партийно-позиционными факторами, охарактеризованными в нашем обзоре, зависимости между антииммигрантскими аттитюдами участников опросов и их голосованием за РПП.

\section{ПРОБЛЕМА, ЗАДАЧИ И ГИПОТЕЗЫ ИССЛЕДОВАНИЯ}

Одно из ключевых направлений в исследованиях голосования за радикальные правые партии, наряду с анализом особенностей избирателей (их социальных характеристик, политических взглядов, отношения к иммиграции и ценностных предпочтений) и партийных организаций (устройства и лидеров), связано с изучением общественных условий, главным образом в Западной Европе, способствующих электоральной поддержке этих партий.

Согласно теоретическим представлениям, повышение в последние десятилетия общественного спроса на националистическую идеологию с авторитарной и традиционалистской окраской вызвано в развитых странах процессами постмодернизации и глобализации. Они вели к ухудшению положения менее образованных и квалифицированных слоев, мелких предпринимателей и вызывали обратную реакцию на произошедшие в культуре либеральные изменения (признание мультикультурализма, обеспечение равенства прав женщин и меньшинств, экологические требования и разнообразие стилей жизни).

Поскольку антииммигрантские призывы являются отличительной чертой радикальных националистов, в исследованиях предполагалось, что благоприятная для правых радикалов ситуация складывается 
при увеличении потока иммигрантов, способствующего обострению межгрупповых экономических и культурных конфликтов в стране. Их поддержке может также способствовать обострение экономической конкуренции с приезжими, обусловленное проблемами в экономике страны и усиливающейся безработицей. Еще одним важным фактором может стать рост преступности, поскольку в интерпретации националистических партий он связывается с иммиграцией.

Работы, посвященные отмеченным структурным различиям между европейскими странами, дополняет анализ политических возможностей - особенностей электоральных и политических институтов, которые обеспечивают многопартийность и парламентское представительство малым партиям, в том числе правым радикалам. Такие возможности появляются при большей децентрализации политических институтов и в электоральной системе, устроенной по принципу пропорционального представительства с низкими порогами прохождения в парламент. Важное место в исследованиях отводится предвыборной партийной конкуренции. Снижение в развитых странах значимости экономических вопросов и проблем перераспределения, а также их классового структурирования, вело к сближению идеологических позиций социально-демократических и консервативных партий. Это побуждало часть их электората к поддержке радикалов, особенно в тех странах, где большая значимость стала придаваться социокультурным проблемам (иммиграция, права женщин, ЛГБТ, других меньшинств, экология), а партийные позиции по ним отличались большей поляризацией.

Эмпирическая проверка предположений о влиянии контекстуальных факторов на голосование за РПП осуществлялась первоначально на экологическом уровне. Полученные партиями голоса в странах Западной (как правило) Европы (за достаточно продолжительный период, охватывающий ряд парламентских выборов, начиная с 1980-х годов, когда правые радикалы становятся заметными), анализировались в зависимости от показателей структурных различий и политических возможностей. В некоторых работах статистический анализ проводился с помощью двухуровневого моделирования: голосование участников опросов за РПП в нескольких десятках стран и ряде парламентских выборов оценивалось при контроле их индивидуальных характеристик и воздействии контекстуальных факторов. При построении двухуровневых моделей предпринимались также попытки, все еще недостаточ- 
ные, изучения межуровневых интеракций - степени выраженности зависимостей между голосованием и индивидуальными характеристиками респондентов в общественных условиях, описываемых контекстуальными факторами. Результаты этих исследований, отчасти подкрепляя приведенные теоретические соображения, все же не дают однозначного ответа на вопрос о значении общественных отличий для голосования за РПП.

Цель настоящей работы - проверить, используя многоуровневое моделирование, выдвинутые в предшествующих исследованиях предположения о зависимости электоральной поддержки радикальных националистов в странах Европы от общественных условий - постмодернизации и изменения культуры, структурных факторов и политических возможностей. В отличие от наших предшественников, в фокусе внимания будут межуровневые взаимодействия между переменными индивидуального уровня и контекстуальными факторами. Важнейшая индивидуальная переменная, побуждающая избирателей в Западной и Восточной (хотя и в существенно меньшей степени) Европе голосовать за правых радикалов, - их отношение к иммиграции. С ростом неприязни к ней значительно повышается вероятность поддержки РПП. Можно ожидать, что эта зависимость с особой отчетливостью будет проявляться в «благоприятных» общественных контекстах после европейского миграционного кризиса 2015 г. (В связи с этим нам приходится при сравнительном анализе ограничиться сравнительно небольшим - около тридцати - набором стран, в которых респонденты сообщали о своем голосовании, пришедшимся на эти годы.) Рассматриваемые контекстуальные факторы позволяют различать а) страны Западной и Восточной Европы и характеризуют б) экономику и неравенства, в) социальное государство, г) иммиграцию, д) преступность, е) электоральную систему, ж) идеологические позиции партий, 3) культурные ценности и, наконец, и) общий уровень постмодернизации. В работе ставились две основные задачи. Первая - проверить, связаны ли различия между странами Европы в результатах голосования на парламентских выборах за РПП с контекстуальными факторами, а вторая, главная задача - выяснить, как эти факторы влияют на мобилизацию избирателей, недовольных иммиграцией.

В исследовании предполагается, что развитие по траектории постмодернизации (расширение сектора услуг и производства знаний в экономике, сильное социальное государство, ценностный сдвиг 
в культуре от материализма и ориентаций на устранение тревоги к предпочтениям, связанным с личностным развитием) оставляет некоторые (главным образом низко статусные) слои в неблагоприятном положении и вызывает электоральную мобилизацию националистических, глубоко консервативных и популистских сил, голосующих за РПП, в противовес сторонникам либеральных изменений в культуре, ставших за последние десятилетия общественным большинством, на которое ориентируются ведущие политические партии. Возможно, эта мобилизация приносит правым радикалам особенно много голосов среди тех, кто с неприязнью относится к иммиграции.

После миграционного кризиса 2015 г. одним из важнейших контекстуальных факторов, стимулирующих голосование за РПП, выступает, надо полагать, присутствие в стране большого числа приезжих и быстрые темпы их прироста. В таком контексте избиратели, недовольные иммиграцией, будут особенно склонными к тому, чтобы отдать свой голос крайним националистам. Не исключено также, что экономическая конкуренция с иностранцами за рабочие места может обостряться в периоды экономического неблагополучия - при высокой безработице, так что ее уровень в разных европейских странах способен объяснить расхождение в процентах голосов, отданных в них за РПП, в немалой степени вследствие побуждения к этому избирателей, недовольных иммиграцией. Негативные зависимости между таким голосованием и уровнем безработицы в странах Западной Европы, обнаруженные в некоторых работах, показывают, что экономическое неблагополучие способно снижать значимость социокультурных проблем, возвращая избирателей к выбору между центристскими левыми и правыми партиями, поскольку радикальные правые не считаются компетентными в решении экономических задач. Еще одно важное условие поддержки правых националистов связано с высокими уровнями преступности в стране, поскольку они выступают за ужесточение наказаний, «закон и порядок», связывая рост правонарушений с приездом иммигрантов. Вполне возможно, что при высоких показателях преступности в стране как раз противники иммиграции будут с большим энтузиазмом поддерживать эти партии.

Различия политических возможностей, связанные с вероятностью представительства в парламентах небольших и новых партий, наличием незанятого пространства в правой части идеологического спектра, большей значимостью в партийных программах социокультурных, чем 
экономических проблем, а также с выраженной с большей отчетливостью поляризацией партийных позиций в культурном измерении по сравнению с экономическим, могут, как мы полагаем, объяснять, почему в одних странах националистические партии собирают больше голосов избирателей, чем в других. Однако трудно предположить, как такие политические возможности будут воздействовать на избирателей, отличающихся своим отношением к иммиграции. Тем не менее, учитывая полученные нами ранее результаты [Сафронов 2019], указывающие на более отчетливое проявление зависимости между поддержкой на выборах РПП и неприятием иммиграции в странах, партийные системы которых были сильнее поляризованы в социокультурном измерении, в исследовании предполагается выяснить, действительно ли при благоприятных для РПП политических условиях их сторонники, неприязненно относящиеся к иммиграции, будут диспропорционально представлены в электорате этих партий.

\section{ЭМПИРИЧЕСКИЕ ДАННЫЕ И МЕТОДЫ АНАЛИЗА}

Решение поставленных задач и проверка гипотез осуществлялись с использованием данных представительных опросов населения в странах Западной и Восточной Европы, выполненных по программе Европейского социального исследования в 2018-2019 гг. (European Social Survey) [ESS Round 9...2018]. В этом раунде участвовали (ко времени проведения исследования) Австрия, Бельгия, Болгария, Венгрия, Великобритания, Германия, Ирландия, Испания, Италия, Кипр, Латвия, Литва, Нидерланды, Норвегия, Польша, Португалия, Сербия, Словакия, Словения, Финляндия, Франция, Хорватия, Черногория, Чехия, Швейцария, Швеция, Эстония (материалы о некоторых странах появились позднее и не рассматривались). К ним была добавлена Россия (материалы ESS 8 раунда) [ESS Round 8...2016], и общее число стран стало равняться двадцати восьми. Для анализа отобраны респонденты, участвовавшие в парламентских выборах, предшествующих опросам, и родившиеся в данной стране (не иммигранты). Их общее число более 25 тыс. человек.

\section{Голосование за радикальные правые партии}

Во время анкетирования участникам опросов предлагалось указать, за какую партию они проголосовали на последних выборах в нацио- 
нальный парламент (нижнюю палату). Зависимая переменная в исследовании представлена дихотомическим признаком, разделяющим опрошенных на тех, кто отдал свой голос одной из радикальных правых партий (градация «1»), и избирателей любой другой политической партии (градация «0»). Классификация партий производилась с учетом мнений исследователей РРП (см.: [The Oxford Handbook of Radical Right...2018] и другие работы, упоминавшиеся в обзоре состояния дел), она представлена в таблице 1. Отметим, что радикальные правые партии существовали и принимали участие в выборах во всех изучавшихся странах. В некоторых из них они собирали значительное число голосов, как, например, Швейцарская народная партия $(29,4$ \%), Австрийская партия свободы (26 \%), Партия финнов $(17,6 \%)$, Шведские демократы (17,5 \%), Лига в Италии $(17,4$ \%) или Партия прогресса в Норвегии $(15,2$ \%) и Национальный фронт во Франции $(13,2$ \%). В других странах такие партии едва привлекали доли процентов избирателей, как, скажем, в Ирландии, Португалии и Испании, Литве, Черногории и Хорватии (и могли отсутствовать в списках партий, о которых имеются опросные данные ESS).

\section{Антииммигрантские убеждения}

Основная независимая переменная индивидуального уровня убеждения респондентов, связанные с их отношением к иммиграции. Их позволяют зафиксировать три следующих анкетных вопроса: 1. «Как вы считаете, то, что люди из других стран переезжают в [страна], в целом плохо или хорошо сказывается на экономике [страна]?» (11-балльная шкала, 0 - плохо для экономики, 10 - хорошо для экономики), 2. «...как вы считаете, приток людей из других стран скорее разрушает или скорее обогащает культуру [страна]?» (11-балльная шкала, 0 - разрушает культуру нашей страны, 10 - обогащает культуру нашей страны), 3. «Как вы считаете, с притоком людей из других стран [страна] как место для жизни становится лучше или хуже?» (11-балльная шкала, 0 - становится хуже, 10 - становится лучше). Эти признаки очень тесно взаимосвязаны (для общего массива респондентов среднее значение Pearson's $\mathrm{r}=0.70, \mathrm{p}<0.000$, Cronbach's Alpha=0.88), что позволяет измерять отношение к иммиграции с помощью обобщающего индекса выраженности антииммигрантских убеждений, который рассчитывался как среднее арифметическое значение для трех указанных шкал после изменения их полярности. 
Таблица 1

Радикальные правые партии в ESS странах

\begin{tabular}{|c|c|c|c|c|}
\hline \multirow{2}{*}{\begin{tabular}{|c|} 
СТРАНА \\
АВСТРИЯ \\
\end{tabular}} & \multicolumn{2}{|r|}{ НАЗВАНИЕ } & \multirow{2}{*}{$\begin{array}{c}\begin{array}{c}\text { Голоса, } \\
\%\end{array} \\
26.0 \\
\end{array}$} & \multirow{2}{*}{$\begin{array}{c}\begin{array}{c}\text { Дата } \\
\text { выборов }\end{array} \\
15.10 .2017\end{array}$} \\
\hline & FPÖ & \begin{tabular}{|l|} 
Австрийская \\
партия свободы
\end{tabular} & & \\
\hline \multirow{2}{*}{ БЕЛЬГИЯ } & $\mathrm{VB}$ & $\begin{array}{l}\text { Фламандский } \\
\text { интерес }\end{array}$ & 3.7 & \multirow[t]{2}{*}{25.05 .2014} \\
\hline & $\mathrm{PP}$ & Народная партия & 1.5 & \\
\hline БОЛГАРИЯ & OP & $\begin{array}{l}\text { Объединенные } \\
\text { патриоты (Атака, } \\
\text { ВMPO-Болгарское } \\
\text { национальное } \\
\text { движение VMRO- } \\
\text { BND, Националь- } \\
\text { ный фронт спасе- } \\
\text { ния Болгарии } \\
\text { NFSB) } \\
\end{array}$ & 9.1 & 26.03 .2017 \\
\hline ВЕНГРИЯ & JOBBIK & \begin{tabular}{|l|} 
Движение за \\
лучшую Венгрию
\end{tabular} & 20.2 & 08.04.2018 \\
\hline ВЕЛИКОБРИТАНИЯ & UKIP & $\begin{array}{l}\text { Партия независи- } \\
\text { мости Соединенно- } \\
\text { го Королевства }\end{array}$ & 1.8 & 08.06 .2017 \\
\hline \multirow[b]{2}{*}{ ГЕРМАНИЯ } & AfD & $\begin{array}{l}\text { Альтернатива } \\
\text { для Германии }\end{array}$ & $\begin{array}{l}11.5 \\
12.6\end{array}$ & \multirow[b]{2}{*}{24.09 .2017} \\
\hline & NPD & $\begin{array}{l}\text { Национал-демокра- } \\
\text { тическая партия } \\
\text { Германии } \\
\end{array}$ & $0.1 ; 0.4$ & \\
\hline \multirow[t]{2}{*}{ ИРЛАНДИЯ } & $(N P)$ & \begin{tabular}{|l|} 
Католические \\
демократы (Нацио- \\
нальная партия) \\
\end{tabular} & 0.1 & \multirow[t]{2}{*}{26.02 .2016} \\
\hline & $\begin{array}{l}\text { Identity } \\
\text { Ireland }\end{array}$ & $\begin{array}{l}\text { Идентичная } \\
\text { Ирландия } \\
\end{array}$ & $<0.05$ & \\
\hline \multirow[b]{2}{*}{ ИСПАНИЯ } & Vox & Голос & 0.2 & \multirow[b]{2}{*}{26.06 .2016} \\
\hline & FE-JONS & $\begin{array}{l}\text { Испанская фаланга } \\
\text { и ХОНС }\end{array}$ & 0.04 & \\
\hline \multirow{4}{*}{ ИТАЛИЯ } & LEGA & Лига & 17.4 & \multirow{4}{*}{04.03 .2018} \\
\hline & FdI & Братья Италии & 4.4 & \\
\hline & CPI & Дом Паунда & 0.9 & \\
\hline & $F N-F T$ & $\begin{array}{l}\text { Италия для } \\
\text { итальяниев }\end{array}$ & 0.4 & \\
\hline
\end{tabular}


Продолжение таблищы 1

\begin{tabular}{|c|c|c|c|c|}
\hline \multirow{2}{*}{\begin{tabular}{|l} 
CТРАНА \\
КИПР \\
\end{tabular}} & \multicolumn{2}{|c|}{ НАЗВАНИЕ } & \multirow{2}{*}{$\begin{array}{c}\begin{array}{c}\text { Голоса, } \\
\%\end{array} \\
3.7 \\
\end{array}$} & \multirow{2}{*}{$\begin{array}{c}\begin{array}{c}\text { Дата } \\
\text { выборов }\end{array} \\
22.05 .2016 \\
\end{array}$} \\
\hline & ELAM & $\begin{array}{l}\text { Национальный } \\
\text { народный фронт }\end{array}$ & & \\
\hline \multirow{2}{*}{ ЛАТВИЯ } & NA & $\begin{array}{l}\text { Национальный } \\
\text { альянс }\end{array}$ & 11.0 & \multirow{2}{*}{06.10 .2018} \\
\hline & & $\begin{array}{l}\text { Латвийские нацио- } \\
\text { налисты }\end{array}$ & 0.5 & \\
\hline ЛИТВА & (JL-LTS) & $\begin{array}{l}\text { Против коррупции } \\
\text { и бедности (Молодая } \\
\text { Литва, Литовский } \\
\text { националистический } \\
\text { и республиканский } \\
\text { союз) }\end{array}$ & 0.6 & 10.2016 \\
\hline \multirow[b]{2}{*}{ НИДЕРЛАНДЫ } & PVV & Партия свободы & 13.1 & \multirow[b]{2}{*}{ 15.03.2017 } \\
\hline & FvD & $\begin{array}{l}\text { Форум за демокра- } \\
\text { тию }\end{array}$ & 1.8 & \\
\hline НОРВЕГИЯ & FrP & Партия прогресса & 15.2 & 11.09 .2017 \\
\hline ПОЛЬША & Kukiz'15 & $\begin{array}{l}\text { Кукиз'15 } \\
\text { (RN, Национальное } \\
\text { движение) } \\
\end{array}$ & 8.8 & 25.10 .2015 \\
\hline ПОРТУГАЛИЯ & PNR & $\begin{array}{l}\text { Партия националь- } \\
\text { ного обновления }\end{array}$ & 0.5 & 04.10 .2015 \\
\hline \multirow{2}{*}{ РОССИЯ } & ЛДПР & $\begin{array}{l}\text { Либерально-демо- } \\
\text { кратическая партия } \\
\text { России }\end{array}$ & $\begin{array}{l}13.4 \\
10.1\end{array}$ & \multirow{2}{*}{ 18.09.2016 } \\
\hline & РОДИНА & \begin{tabular}{|l|} 
Всероссийская \\
политическая \\
партия «Родина»
\end{tabular} & $1.5,2.5$ & \\
\hline \multirow{3}{*}{ СЕРБИЯ } & SRS & $\begin{array}{l}\text { Сербская радикаль- } \\
\text { ная партия }\end{array}$ & 8.1 & \multirow{3}{*}{24.04 .2016} \\
\hline & Dveri & $\begin{array}{l}\text { Сербское движение } \\
\text { Двери }\end{array}$ & 5.0 & \\
\hline & $S S Z$ & \begin{tabular}{|l} 
Сербская партия \\
Заветниии (храни- \\
тели заветов)
\end{tabular} & 0.7 & \\
\hline \multirow{3}{*}{ СЛОВАКИЯ } & SNS & $\begin{array}{l}\text { Словацкая нацио- } \\
\text { нальная партия }\end{array}$ & 8.6 & \multirow{3}{*}{05.03 .2016} \\
\hline & LSNS & $\begin{array}{l}\text { Народная партия - } \\
\text { наша Словакия }\end{array}$ & 8.0 & \\
\hline & $\begin{array}{c}\text { Sme } \\
\text { Rodina }\end{array}$ & Мы семья & 6.6 & \\
\hline
\end{tabular}


Окончание таблицы 1

\begin{tabular}{|c|c|c|c|c|}
\hline СТРАНА & \multicolumn{2}{|r|}{ НАЗВАНИЕ } & $\begin{array}{c}\text { Голоса, } \\
\%\end{array}$ & $\begin{array}{c}\text { Дата } \\
\text { выборов }\end{array}$ \\
\hline СЛОВЕНИЯ & SNS & $\begin{array}{l}\text { Словенская нацио- } \\
\text { нальная партия }\end{array}$ & 4.2 & 03.06 .2018 \\
\hline ФИНЛЯНДИЯ & PS & Партия финнов & 17.6 & 19.04 .2015 \\
\hline \multirow[b]{2}{*}{ ФРАНЦИЯ } & $\mathrm{FN}$ & $\begin{array}{l}\text { Национальный } \\
\text { фронт (1-й раунд) }\end{array}$ & 13.2 & \multirow[b]{2}{*}{ 8.06.2017 } \\
\hline & MNR & $\begin{array}{l}\text { Национальное } \\
\text { республиканское } \\
\text { движение }\end{array}$ & & \\
\hline \multirow[b]{2}{*}{ ХОРВАТИЯ } & $\begin{array}{c}\text { Coalition } \\
\text { Move }\end{array}$ & $\begin{array}{l}\text { Коалиция HSP, } \\
H \check{S P}, A B H, O S\end{array}$ & 0.7 & \multirow[b]{2}{*}{11.09 .2016} \\
\hline & $\begin{array}{l}\text { Homeland } \\
\text { Coalition }\end{array}$ & $\begin{array}{l}\text { Коалиция HSP AS, } \\
\text { Desno, HKDU, USP, } \\
\text { HDS }\end{array}$ & 0.6 & \\
\hline ЧЕРНОГОРИЯ & SSR & $\begin{array}{l}\text { Партия сербских } \\
\text { радикалов }\end{array}$ & 0.18 & 16.10 .2016 \\
\hline ЧЕХИЯ & SPD & $\begin{array}{l}\text { Свобода и прямая } \\
\text { демократия }\end{array}$ & 10.6 & $\begin{array}{c}20- \\
21.10 .2017 \\
\end{array}$ \\
\hline \multirow[t]{2}{*}{ ШВЕЙЦАРИЯ } & SVP & $\begin{array}{l}\text { Швейцарская } \\
\text { народная партия }\end{array}$ & 29.4 & \multirow[t]{2}{*}{18.10 .2015} \\
\hline & LEGA & Лига Тичино & 1.0 & \\
\hline \multirow{3}{*}{ ШВЕЦИЯ } & SD & $\begin{array}{l}\text { Шведские демокра- } \\
\text { ты }\end{array}$ & 17.5 & \multirow{3}{*}{ 09.09.2018 } \\
\hline & AfS & $\begin{array}{l}\text { Альтернатива } \\
\text { для Швеции }\end{array}$ & 0.3 & \\
\hline & $N M R$ & $\begin{array}{l}\text { Северное движение } \\
\text { сопротивления }\end{array}$ & 0.03 & \\
\hline \multirow{2}{*}{ ЭСТОНИЯ } & EKRE & $\begin{array}{l}\text { Консервативная } \\
\text { народная партия } \\
\text { Эстонии }\end{array}$ & 8.1 & \multirow[t]{2}{*}{ 01.03.2015 } \\
\hline & EIP & $\begin{array}{l}\text { Эстонская партия } \\
\text { независимости }\end{array}$ & 0.2 & \\
\hline
\end{tabular}

Курсивом отмечены партии, о которых нет сведений в опросных данных ESS

Влияние антииммигрантских убеждений на голосование за РПП оценивалось при контроле важных, согласно результатам исследований, дифференцирующих признаков социальной демографии - пола $(0-$ Ж, $1-\mathrm{M}$ ), возраста (в годах) и образования (суммарное число лет 
обучения в формальных образовательных учреждениях - школе, колледже, институте или университете, аспирантуре и т.п.).

\section{Измерение общественного контекста}

Различия между 28 странами Европы описывались с помощью восьми блоков контекстуальных факторов.

1. ЧАСТЬ ЕВРОПЫ

- Западная / Восточная Европа. К Западной Европе (градация «0») отнесены пятнадцать стран, включая Австрию, Бельгию, Великобританию, Германию, Ирландию, Испанию, Италию, Кипр, Нидерланды, Португалию, Норвегию, Финляндию, Францию, Швейцарию и Швецию, а к Восточной (градация «1») - тринадцать: Болгария, Венгрия, Латвия, Литва, Польша, Россия, Сербия, Словакия, Словения, Хорватия, Чехия, Черногория, Эстония.

2. ЭКОНОМИКА и НЕРАВЕНСТВА (по материалам The World Bank Group, http://data.worldbank.org/data-catalog/world-development-indicators, приведенным в базе данных QoG, Quality of Government [Teorell et al. 2020]).

- ВВП на душу населения (GDP per capita, PPP, constant 2011 international \$, в годы выборов);

- Безработные, доля (Unemployment, \% of total labor force, в годы выборов);

- Джини-индекс (GINI index, 2015, 2014);

- Сектор услуг, доля занятых (Employment in services, \% of total employment, 2015).

3. СОЦИАЛЬНОЕ ГОСУДАРСТВО

- Общественные расходы на соииальную защиту, на душу населения (\$, рассчитаны по данным Public social protection expenditure 2014-2015, \% GDP [ILO...2017: table B.16]).

4. ИММИГРАЦИЯ (по: [United Nations...2017])

- Иммигранты, доля (International migrant stock, \% of the total population, 2017);

- Темпы изменения доли иммигрантов (Annual rate of change of the migrant stock, 2010-2015).

5. ПРЕСТУПНОСТЬ

- Нападение на близких людей, доля - агрегированный показатель по ESS опросам, полученный в ответах на вопрос анкеты «Были ли случаи за последние 5 лет, когда вы или члены вашей семьи стали жертвами грабежа или нападения, насилия?» («Да, были случаи»); 
- Воровство на 100 mыс. (Theft per 100000, в год выборов, по данным UN Office on Drug and Crime, URL: https://dataunodc.un.org/data/ crime/theft /дата обращения: 08.10.2021/).

6. ПАРТИЙНАЯ СИСТЕМА

- Действительное число партий (по полученным голосам) (Еffective number of parties on the votes level), рассчитывалось по формуле [Laakso, Taagepera 1979: 4]:

$$
N=1 \div \sum_{i=1}^{n} p_{i}^{2}
$$

где $p_{i}-$ доли голосов, полученных каждой из партий.

Ряд показателей, характеризующих партийные системы европейских стран, базировался на сведениях об идеологических позициях партий в экономическом и культурном измерениях. Они рассчитывались при обращении к результатам контент-анализа предвыборных партийных «манифестов» - программ или сходных документов (Manifesto Research on Political Representation, MARPOR, cm.: [Volkens et al. 2020a]). Эти материалы позволяют охарактеризовать за многие годы все заметные партии в странах Европы, получавшие хотя бы одно место в национальном парламенте. Идеологический профиль каждой партии описывается в MARPOR с помощью набора контент-аналитических категорий, каждая из которых в результате анализа текста, разбитого на «псевдопредложения», получает оценку, соответствующую процентной доли ее упоминаний в предвыборной программе [Volkens et al. 2020b]. По этим данным были сконструированы показатели традиционного политического конфликта, связанного с экономикой и социальным государством, и новой политики, отражающей размежевание по социокультурным проблемам. Они характеризуют партийные системы представленных в ESS стран в годы избрания парламентов, в котором участвовали респонденты этих опросов (исключения - Россия, последние сведения в MARPOR относятся к избранию Государственной Думы в 2011 г., а не в 2016 г., и Венгрия с выборами в Национальное Собрание 2014 г., а не 2018 г., что вряд ли существенно отразилось на идеологическом структурировании их партийных систем к следующим выборам, отраженным в ESS).

Об экономическом разделении на левых и правых свидетельствуют два обобщенных индекса. Один суммирует категории, указывающие 
на рьночныцй идеологический полюс: «свободная рыночная экономика» (одобрительные упоминания свободного рынка и рыночного капитализма, свободной конкуренции, прав частной собственности, предпринимательской инициативы, устранения ограничений для предпринимательства) (имя переменной в базе данных - per401); «ограничение социального государства» (ограничение государственных расходов на социальное обеспечение и страхование, приоритет частного перед государственным) (per505); «экономическая ортодоксия» (уменьшение бюджетного дефицита, сокращение расходов, бережливость) (per414); «стимуляция: позитивная оценка» (мотивация бизнеса, налоговые льготы и субсидии, стимулирующая политика в отношении заработной платы и налогов, поощрения для начала предпринимательской деятельности) (per402); «протекционизм: негативная оценка» (поддержка свободной торговли и открытых рынков, отмена средств защиты рынка) (per407); «трудовые объединения: негативная оценка» (отрицательные указания на трудовые объединения и профсоюзы) (per702); «ограничения на образование» (урезание государственных расходов на образование, расширение платного обучения, числа частных школ) (per507). Второй индекс получается при подсчете суммы оценок по категориям, указывающим на важную регулируюшую роль государства в экономике и соииальном развитии: «контролируемая экономика» (поддержка прямого влияния правительства на экономику, контроль цен, минимальной оплаты труда) (per412); «национализация» (одобрение государственной собственности в промышленности, на землю, сохранение национализированных предприятий за государством, национализация частных предприятий) (per413); «расширение социального государства» (увеличение государственных расходов на здравоохранение, уход за детьми и пожилыми людьми, пенсии, социальное жилье) (per504); «регулирование рынка» (защита потребителей, малого бизнеса, социальная рыночная экономика, обеспечение экономической конкуренции) (per403); «протекционизм: позитивная оценка» (поддержание и расширение защиты внутренних рынков, введение тарифов, квот, экспортных субсидий) (per406); «трудовые объединения: позитивная оценка» (позитивные упоминания трудовых объединений, рабочего класса, безработных, поддержка профсоюзов, улучшение условий труда и заработной платы) (per701); «поддержка образования» (увеличение государственных расходов на образование, сокращение платного обучения, числа частных школ) (per506). 
Разделение партийных позиций в социокультурном измерении также фиксировалось с помощью двух интегральных показателей. Первый указывает на выраженность в предвыборных программах партий идеологии консервативного национализма. Он представляет собой суммарную долю позитивных упоминаний категорий «национальный образ жизни» (одобрение нации, ее истории, принятых национальных идей, апелляции к гражданской гордости, патриотизму, национализм, ограничение свобод для защиты государства от подрывной деятельности) (имя переменной в базе данных - per601); «традиционная мораль» (одобрительные указания на традиционные, религиозные моральные ценности, запрещение, цензура, подавление безнравственности и неподобающего поведения) (per603); «закон и порядок» (необходимость обеспечения строгого правопорядка, жестких мер в борьбе с преступностью, усиление полиции, строгость в судах, важность внутренней безопасности) (per605); и негативных указаний на «мультикультурализм» (важность культурной однородности общества, осуществления и поощрения культурной интеграции) (per608); «Европейское сообщество, Европейский Союз» (отрицательные упоминания этих образований, неприятие решений Европейских властей, отчислений страны в бюджет ЕС) (per110); «интернационализм» (негативные отзывы о международном сотрудничестве, позитивные о национальной независимости и суверенитете при проведении внешней политики страны, изоляционизме и односторонности в противовес интернационализму) (per109). Второй показатель свидетельствует о склонности к либеральному космополитизму. Для его вычисления складывались доли негативных категорий «национальный образ жизни» (неприязненные упоминания нации, истории страны, неприятие патриотизма, национализма, национальной гордости и национальной идеи) (per602); «традиционная мораль» (оппозиция традиционным, религиозным моральным ценностям, признание приемлемости разводов и абортов, современных семейных отношений, отделения церкви от государства) (per604) и позитивных указаний на «мультикультурализм» (благосклонность к культурному разнообразию и многообразию внутри страны, сохранение в ней автономии религиозного и языкового наследия) (per607); «Европейское сообщество, Европейский Союз» (одобрение этих образований, желательность вхождения страны в ЕС, важность его расширения, увеличение сферы компетенции Европейского Союза, Европейского парламента) (per108); «интер- 
национализм» (необходимость международной кооперации, важность помощи развивающимся странам, всемирного регулирования ресурсов, глобального правления, международных судов, поддержки ОOH, международных организаций) (per107); «ограниченные в правах меньшинства» (общие указания на ограничения прав меньшинств, таких как иммигранты, представители коренных народов, гомосексуалисты) (per 705).

Показатели экономического и социокультурного позиционирования партий служили для конструирования ряда переменных, в том числе для измерения экономической и культурной значимости и поляризации партийных систем (при этом учитывались подходы, обсуждаемые в [Dalton 2008; Sigelman, Yough 1978; Spies 2013; Spies, Franzmann 2011]).

- Позииия основной правой партии в культурном измерении. Оценивалась предвыборная идеология христианско-демократических и консервативных партий, играющих важную роль в формировании правительств или оппозиции, с использованием переменной позиционирования в социально-культурном измерении, представляющей собой разность между показателями консервативного национализма и либерального космополитизма (положительные значения говорят о преобладании националистических мотивов, а отрицательные - космополитических представлений).

- Обобщенная позиция партийной системь в культурном измерении. Для всех участвовавших в выборах партий суммировались значения переменной позиционирования в социально-культурном измерении (разность консервативного национализма и либерального космополитизма), взвешенные долей полученных ими голосов.

- Значимость экономической идеологии в партийной системе. Это взвешенная долей голосов сумма позиций всех партий по индексам рыночной ориентации и государственного контроля.

- Значимость соииокультурной идеологии в партийной системе. Показатель является суммой позиций всех партий по индексам консервативного национализма и либерального космополитизма, взвешенных долей полученных голосов.

- Отношение экономической значимости к культурной значимости. Высокие значения говорят о большей важности для конкурирующих партий экономических проблем по сравнению с социокультурными вопросами, а низкие, напротив, о придании важности культурным проблемам, рассматриваемым в соотнесении с экономическими. 
- Поляризаиия партий в экономическом измерении. Рассчитывалась по разности индексов рыночной ориентации и государственного контроля, характеризующих позицию каждой участвовавшей в выборах партии, с применением приведенной ниже формулы.

- Поляризация партий в культурном измерении. Также по нижеприведенной формуле для разности индексов консервативного национализма и либерального космополитизма:

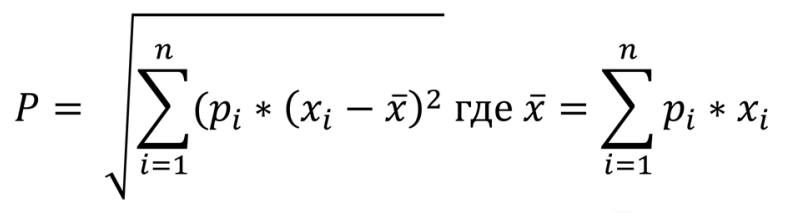

$p_{i}$ - доли голосов, полученных каждой из партий, $x_{i}-$ значение для данной партии разности индексов рыночной ориентации и государственного контроля или консервативного национализма и либерального космополитизма.

7. КУЛЬТУРНЫЕ ЦЕННОСТИ

- Устранение тревоги или развитие: преобладающие в культуре страны ценности. По данным ESS вычислялись индексы ценностных ориентаций респондентов, соответствующих теоретическим представлениям Ш. Шварца [Schwartz 1992; 2012] и измеренных с помощью разработанного им опросника [Schwartz 2001]. Агрегированные средние значения этих ориентаций [Schwartz 2006], выражающие особенности культуры 28 стран, подвергались факторному анализу (метод главных компонент). С латентной переменной культурных ценностей положительно коррелировали показатели «универсализма» (0.89), «саморазвития» $(0.83)$, «доброжелательности» $(0.87)$, «гедонизма» $(0.75)$ и отрицательно - ориентации на «достижение» $(-0.81)$, «власть» $(-0.85)$, «безопасность» $(-0.72)$ и «подчинение» $(-0.62)$ (все статистически значимые при $\mathrm{p}<0.000$; Eigenvalue $=5.04 ; \%$ of Variance $=63 \%)$. Для каждой страны вычислялось значение факторного индекса, отражающего это решение, с отрицательным полюсом «устранение тревоги» и положительным - «устремление к развитию» (используя терминологию Ш. Шварца). Стремление устранить тревогу характерно для таких стран, как Болгария, Италия, Литва, Россия, Польша, и других представителей Восточной Европы, тогда как на развитие сориентированы страны Западной Европы - наиболее отчетливо Швеция, Финляндия, Франция, Германия, Швейцария и Нидерланды. 


\section{8. ПОСТМОДЕРНИЗАЦИЯ}

- Факторный индекс постмодернизаиии. Отражает различия между странами Европы по нескольким взаимосвязанным контекстуальным переменным, указывающим на неодинаковое развитие обществ в постиндустриальном направлении. Метод главных компонент (Eigenvalue $=3.86, \%$ of Variance $=77 \%$ ) показывает, что в один фактор входят разделение Восточная / Западная Европа (факторная нагрузка 0.94), душевой ВВП (0.87), доля занятых в секторе услуг (0.82), государственные расходы на социальную защиту (0.93) и культурное разделение устранение тревоги / развитие (0.82). Относительно более низкие значения индекса постмодернизации характерны для Сербии, Болгарии, Польши, России, Литвы, других посткоммунистических стран, а более высокие - для Норвегии, Швеции, Швейцарии, Ирландии, Франции, Нидерландов, Финляндии и других Западных демократий.

\section{Статистический аппарат и схема анализа}

Исследование влияния антииммигрантских аттитюдов на голосование за РПП в разных общественных контекстах осуществлялось с помощью двухуровневого логистического моделирования (программный пакет HLM, Hierarchical Linear and Nonlinear Modeling, [Raudenbush, Bryk 2002]. Рассматривались иерархические модели со случайными коэффициентами для переменной, фиксирующей эти аттитюды (при контроле на индивидуальном уровне пола, возраста и образования), и интеракциями между нею и контекстуальными факторами при включении их в уравнение по отдельности и совместно. Обсуждаются моделируемые эффекты, связанные с воздействием контекста на различия в электоральной поддержке РПП в разных странах Европы и с модерацией контекстуальными факторами влияния антииммигрантских убеждений на эту поддержку. Схематическое изображение изучавшихся зависимостей представлено на рисунке 1.

В двухуровневых моделях независимые переменные были преобразованы: на индивидуальном уровне они измерялись в шкалах, изменяющихся от 0 до 1, и в каждой стране центрировались относительно средних значений, а контекстуальные факторы центрировались по отношению к среднему значению для изучавшихся 28 стран и измерялись в стандартных отклонениях. Такие преобразования упрощают статистическое построение моделей и позволяют в первом приближении сопоставлять эффекты, связанные с разными переменными. 
Во многих странах сведения электоральной статистики о доле голосов, отданных за РПП, заметно отличаются от оценок, полученных в ESS опросах (последние, как правило, ниже, что, вероятно, обусловлено нормативным давлением, связанным с неприемлемостью в либеральных демократиях крайних форм национализма и социального консерватизма). В связи с этим опросные данные взвешивались таким образом, чтобы привести опросные показатели в соответствие с официальными данными о результатах выборов.

\section{КОНТЕКСТУАЛЬНЫЕ ФАКТОРЫ И УСПЕХИ РПП В СТРАНАХ ЕВРОПЫ}

Зависимости между долями голосов, которые получают в странах Европы РПП, и различающими эти страны факторами, объединенными в восемь описанных выше блоков, оценивались первоначально на экологическом уровне с помощью анализа парных корреляций. Полученные коэффициенты представлены в таблице 2. Изучавшиеся в ESS европейские страны составляют сравнительно немногочисленную группу, насчитывающую всего двадцать восемь единиц, что затрудняет статистическую проверку значимости выявляемых взаимосвязей между интересующими нас переменными, поскольку, как свидетельствуют результаты исследований, эти связи зачастую достаточно слабые. Многие корреляции, как видно в таблице, действительно оказались низкими и незначимыми.

Уровень поддержки РПП практически не отличается в странах Западной и Восточной Европы. Состояние экономики, ее структура (развитие сектора услуг) и доходные неравенства тоже не дают достоверных объяснений неодинаковой их поддержки. Кроме показателя безработицы: вопреки утверждениям об ее способствующем влиянии на голосование за правых радикалов, наши результаты, как и некоторых других работ, говорят об обратном - с ростом в стране доли безработных несколько снижается процент избирателей этих партий. Усиление социального государства, также в противоречии с утверждениями о его сглаживающем влиянии, способствует укреплению электорального статуса РПП (правда, эта зависимость была очень слабой). Иммиграция, отраженная показателем темпов ее прироста, тоже в определенной мере может создавать для РПП благоприятную почву (также слабая связь). Еще одно условие, способствующее их поддержке на выборах, - широ- 


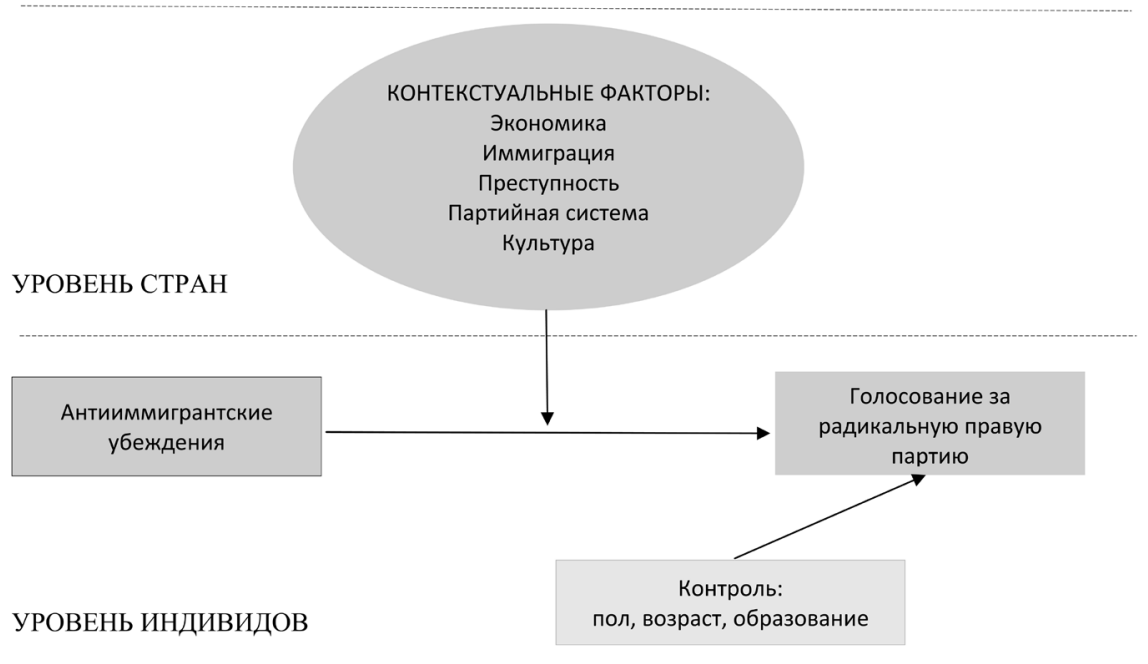

Рисунок 1. Схема анализа голосования за РПП в странах Европы

кое распространение в обществе нетяжких преступлений, таких как кражи (опять же связь слабая). Ни различие культурных ценностей, ни общий показатель постмодернизации не объясняют, почему в одних европейских странах правые националисты имеют значительный электорат, а в других им не удается привлечь на свою сторону избирателей.

Наиболее отчетливые закономерности проявляются с некоторыми контекстуальными факторами, характеризующими партийные системы, но не всеми, о которых высказывались предположения. Индекс действительного числа партий, указывающий на наличие в стране политических возможностей для избрания в парламент небольших и новых партий, оказался на деле не связанным с голосами, отданными РПП. Не обнаружено корреляции и с позициями, которые в социокультурном измерении занимают радикальные правые партии (по показателю разности между консервативным национализмом и либеральным космополитизмом), хотя эти позиции сильно варьируют (в одних странах радикализм правых националистов выражен с полной отчетливостью, тогда как в других они весьма сдержаны).

В то же время, как показывают корреляции в таблице 2, подтверждается предположение о важности позиционирования в культурном измерении правой партии, играющей важную роль в политической системе. Существуют противоположные теоретические ожидания 
Таблиияа 2

Корреляции между голосованием за РПП и контекстуальными факторами

\begin{tabular}{|c|c|c|c|}
\hline ФАКТОРЫ & $\begin{array}{l}\text { Pearson's } \\
\text { r }\end{array}$ & ФАКТОРЫ & $\begin{array}{c}\text { Pearson's } \\
\text { r }\end{array}$ \\
\hline ЧАСТЬ ЕВРОПЫ & & ПАРТИЙНАЯ СИСТЕМА & \\
\hline Западная / Восточная & -0.15 & $\begin{array}{l}\text { Действительное число } \\
\text { партий }\end{array}$ & 0.07 \\
\hline $\begin{array}{l}\text { ЭКОНОМИКА, } \\
\text { НЕРАВЕНСТВА }\end{array}$ & & $\begin{array}{l}\text { Позиция основной } \\
\text { правой партии в куль- } \\
\text { турном измерении } \\
\text { (национализм) }\end{array}$ & $0.49^{* *}$ \\
\hline ВВП (на душу) & 0.31 & $\begin{array}{l}\text { Позиция системы } \\
\text { в культурном измерении } \\
\text { (национализм) }\end{array}$ & $0.62^{\star * *}$ \\
\hline Безработные (доля) & $-0.42 *$ & $\begin{array}{l}\text { Значимость в экономиче- } \\
\text { ском измерении (либера- } \\
\text { лизм) (a) }\end{array}$ & 0.13 \\
\hline Джини-индекс & -0.16 & $\begin{array}{l}\text { Значимость в культур- } \\
\text { ном измерении (нацио- } \\
\text { нализм) (b) }\end{array}$ & $0.53^{* *}$ \\
\hline Сектор услуг (доля) & -0.07 & $\begin{array}{l}\text { Отношение экономиче- } \\
\text { ской и культурной } \\
\text { значимостей (a)/(b) }\end{array}$ & $-0.40^{\star}$ \\
\hline $\begin{array}{l}\text { СОЦИАЛЬНОЕ } \\
\text { ГОСУДАРСТВО }\end{array}$ & & $\begin{array}{l}\text { Поляризация в экономи- } \\
\text { ческом измерении (с) }\end{array}$ & 0.24 \\
\hline $\begin{array}{l}\text { Госрасходы на социальную } \\
\text { защиту (на душу) }\end{array}$ & $0.37^{x}$ & $\begin{array}{l}\text { Поляризация в культур- } \\
\text { ном измерении (d) }\end{array}$ & $0.58^{\star * *}$ \\
\hline ИММИГРАЦИЯ & & $\begin{array}{l}\text { Отношение экономиче- } \\
\text { ской и культурной } \\
\text { поляризаций (c)/(d) }\end{array}$ & $-0.52^{\star *}$ \\
\hline Иммигранты (доля) & 0.23 & $\begin{array}{l}\text { Позиция РПП в культур- } \\
\text { ном измерении (нацио- } \\
\text { нализм) }\end{array}$ & 0.20 \\
\hline $\begin{array}{l}\text { Прирост иммигрантов } \\
\text { (процент) }\end{array}$ & $0.33^{x}$ & $\begin{array}{l}\text { КУЛЬТУРНЫЕ } \\
\text { ЦЕННОСТИ }\end{array}$ & \\
\hline ПРЕСТУПНОСТЬ & & $\begin{array}{l}\text { Устранение тревоги / } \\
\text { Развитие }\end{array}$ & 0.05 \\
\hline
\end{tabular}


Окончание таблиць 2

\begin{tabular}{|c|c|c|c|}
\hline ФАКТОРЫ & $\begin{array}{l}\text { Pearson's } \\
\text { r }\end{array}$ & ФАКТОРЫ & $\begin{array}{l}\text { Pearson's } \\
\text { r }\end{array}$ \\
\hline $\begin{array}{l}\text { Нападение на близких } \\
\text { людей (доля) }\end{array}$ & -0.10 & ПОСТМОДЕРНИЗАЦИЯ & \\
\hline Воровство на 100 тыс. & $0.34^{\times}$ & $\begin{array}{l}\text { Индекс постиндустри- } \\
\text { ального развития }\end{array}$ & 0.19 \\
\hline
\end{tabular}

Уровни значимости: ${ }^{* *} 0.001,{ }^{*} 0.01,{ }^{\star} 0.05,{ }^{\star} 0.10 . \mathrm{N}($ страны $)=28$ (кроме показателя Позиции РПП в культурном измерении $\mathrm{N}=23$ ).

о позициях такой партии для РПП. Согласно одной точке зрения, ее смещение к центру, сближение с левоцентристскими партиями и умеренность в вопросах иммиграции и традиционного консерватизма, побуждает некоторых из ее бывших избирателей голосовать за радикальных националистов, у которых ясная и предельно строгая позиция по этим вопросам. Сторонники другой точки зрения полагают, напротив, что благоприятные условия для правых радикалов складываются в том случае, когда основная правая партия занимает в указанных вопросах достаточно жесткую позицию, тем самым легитимируя РПП. Согласно нашим результатам, смещение основной правой партии по социокультурной оси к полюсу консервативного национализма ведет к увеличению электората правых радикалов, что подтверждает тезис о легитимизации. Он подтверждается и при использовании другого показателя, фиксирующего усредненную позицию партийной системы по оси либеральный космополитизм / консервативный национализм: при сдвиге в националистическом направлении, создающем предпосылки для признания радикализма, заметно увеличивается электоральная поддержка РПП.

С полной определенностью проявляются также зависимости, связанные с предположениями о повышении в современной Европе значимости социокультурной оси политического конфликта, которая отделяет идеологию либерального космополитизма на одном полюсе от консервативного национализма на другом, и о более резком размежевании партий между этими полюсами. Как видно в таблице 2, с ростом значимости в партийной системе страны культурного измерения растет вероятность расширения в ней электорального сегмента, поддерживающего РПП. Относительный рост такой значимости при сопоставлении 
с важностью экономических вопросов, измеренный индексом отношения экономической и культурной значимостей, также показывает, что при высоких значениях этого индекса, когда экономика намного важнее культурных вопросов, националистические популистские партии получают гораздо меньше голосов, чем при низких его значениях, указывающих на растущую значимость социокультурной проблематики.

Кроме того, корреляции между электоральными успехами РПП и индексами, измеряющими идеологическую поляризацию партий, выступающих за либеральный космополитизм / консервативный национализм, оказались еще сильнее, чем с показателями значимости. Вероятность поддержки РПП возрастает по мере усиления поляризации в культурном измерении, когда обостряется противостояние партий, отстаивающих либерально-космополитические и консервативнонационалистические воззрения. Показатель отношения экономической и культурной поляризаций подкрепляет соображение о необходимости учитывать оба идеологических размежевания: правые националисты получают больше голосов в тех странах Европы, которые отличаются низкими значениями этого показателя, указывающими на относительно слабое размежевание по экономическим вопросам в сравнении с культурным противостоянием, тогда как при высоких его значениях резком разделении партийных позиций в вопросах экономики, но не культуры: правые радикалы выступают на парламентских выборах менее успешно.

Таким образом, представленный анализ показывает, что одно из объяснений неодинаковых для РПП результатов парламентских выборов в странах Западной и Восточной Европы связано с особенностями идеологических позиций, которые партии отстаивают в своих предвыборных программах. Кроме традиционного политического противостояния в экономическом измерении необходимо учитывать и то, как партии себя позиционируют в социокультурном измерении - отстаивают ли принципы либерального космополитизма или же выступают в поддержку консервативного национализма. Сдвиг ведущих правых партий в националистическом направлении легитимирует РПП, что позволяет им добиваться лучших результатов при выборах в парламенты. Повышение значимости культурного измерения для партийной системы и усиление поляризации партийных позиций в этом измерении также создают предпосылки для электорального успеха радикальных правых партий. 


\section{ИЗБИРАТЕЛИ РПП В ЗАПАДНОЙ И ВОСТОЧНОЙ ЕВРОПЕ: ЗНАЧЕНИЕ АНТИИММИГРАНТСКИХ УБЕЖДЕНИЙ}

При обосновании проблемы и задач исследования отмечалось, что контекстуальные факторы не только могут объяснять отличия между странами Европы в процентах голосов, которые удается собрать РПП, но и способны мотивировать избирателей, с неприязнью относящихся к иммиграции, проголосовать за эти партии. Прежде чем перейти к систематическому рассмотрению этого соображения, нам предстоит убедиться, что отношение к иммиграции действительно является, как признается исследователями, важнейшей переменной, отделяющей электорат правых националистов от избирателей других партий. Этот факт многократно и убедительно подтверждался при изучении Западной Европы, однако в Восточной Европе, хотя и отмечается растущая в последние годы роль антииммигрантских настроений при голосовании за правых националистов, требуется дальнейшая эмпирическая проверка этого тезиса.

Такая проверка осуществлялась при построении двухуровневых логистических моделей, представленных в таблице 3.

Модель А описывает склонность респондентов голосовать за правых радикалов в зависимости от переменных индивидуального уровня, включая антииммигрантские убеждения и социально-демографический контроль (по полу, возрасту и образованию). Она показывает в согласии с известными зависимостями, что вероятность голосования за РПП выше среди мужчин, в младших возрастах, среди менее образованных участников опросов, и что самой важной причиной, намного перевешивающей все прочие, является негативное отношение избирателей к иммиграции. Причем влияние антииммигрантских убеждений, как показывает статистически значимая на высоком уровне дисперсия, заметно отличается в разных европейских странах.

С целью выяснения, связаны ли неодинаковые воздействия антииммигрантских взглядов на поддержку РПП с разделением на Западную и Восточную Европу, модель В включала дополнительно фактор, описывающий это разделение, и интеракцию этого фактора с переменной отношения к иммиграции. Коэффициент для этой переменной сильно увеличивается (статистически значим на высоком уровне) - теперь он характеризует не усредненное для изучавшихся стран влияние, а то, как оно проявляется в странах Запада. Межуровневой интеракция также ока- 
Таблица 3

Влияние антииммигрантских убеждений на голосование за РПП, различия в Западной/Восточной Европе и при разном отношении в обществе к иммиграции

\begin{tabular}{|c|c|c|c|}
\hline & \multicolumn{3}{|c|}{ МОДЕЛИ } \\
\hline $\begin{array}{l}\text { ФИКСИРОВАННЫЕ ЭФФЕКТЫ } \\
\text { (Коэфбициенть })\end{array}$ & A & $\mathrm{B}$ & $\mathrm{C}$ \\
\hline Intercept & $-3.09^{* * *}$ & $-3.21^{\star * *}$ & $-3.10^{\star * *}$ \\
\hline Пол (M) & $0.44^{* * *}$ & $0.44^{\star * *}$ & $0.44^{* * *}$ \\
\hline Возраст (лет) & $-0.90^{\star * *}$ & $-0.90^{* * *}$ & $-0.90^{* * *}$ \\
\hline Образование (лет) & $-0.89^{*}$ & $-0.88^{\star}$ & $-0.88^{\star}$ \\
\hline Антииммигрантские убеждения & $3.21^{\star * *}$ & $5.15^{\star \star \star}$ & $3.24^{\star * *}$ \\
\hline Западная/Восточная Европа & & 0.19 & \\
\hline Неприятие иммиграции х 3/В Европа & & $-3.91^{\star \star \star}$ & \\
\hline Одобрение иммиграции в обществе & & & -0.53 \\
\hline $\begin{array}{l}\text { Неприятие иммиграции х Одобрение ее } \\
\text { в обществе }\end{array}$ & & & $1.35^{\star * *}$ \\
\hline СЛУЧАЙНЫЕ ЭФФЕКТЫ (Дисперсии) & & & \\
\hline Intercept & $2.93^{* * *}$ & $3.25^{\star * *}$ & $2.84^{\star * *}$ \\
\hline $\begin{array}{l}\text { Неприятие иммиграции } \\
\text { (\% explained) }\end{array}$ & $6.20^{* * *}$ & $\begin{array}{l}2.27^{* * *} \\
(63 \%)\end{array}$ & $\begin{array}{l}4.31^{* * *} \\
(30 \%)\end{array}$ \\
\hline
\end{tabular}

Двухуровневые логистические модели, зависимая переменная - голосование за РПП, независимые переменные 1-го уровня (индивиды) - социальная демография (фиксированные коэффициенты) и индекс антииммигрантских убеждений (случайный коэффициент); контекстуальные факторы - Западная/ Восточная Европа и отношение в стране к иммиграции (средние значения переменной индивидуального уровня). Уровни значимости: ***0.001, * 0.05. N1 (индивиды) $=25702 ; \mathrm{N} 2($ страны $)=28$.

залась отчетливо выраженной (и неслучайной), что свидетельствует о значительных отличиях антииммигрантских мотиваций поддержки правых радикалов в одной и другой части континента (дихотомия Запад/ Восток объясняет 63 \% соответствующей дисперсии). Она лишний раз подтверждает, что в странах Западной Европы голосование за эти партии тесно связано с неприятием избирателями иммиграции. Можно показать, что и в Восточной Европе отторжение иммиграции побуждает к электоральной поддержке РПП, хотя и не во всех странах. В Западной Европе коэффициент влияния антииммигрантских убеждений равняется 5.15 $(\mathrm{p}<0.001)$, а в Восточной он существенно уменьшается - до 1.24 (Odds ratio=3.46), оставаясь, тем не менее, статистически значимым $(\mathrm{p}<0.023)$. 
Итак, представленный анализ убеждает, что негативное отношение к иммиграции - одна из важнейших причин голосования за РПП в Западной Европе, но и в посткоммунистических странах эта переменная имеет немаловажное значение.

\section{АНТИИММИГРАНТСКИЕ ГОЛОСА ЗА РПП И НЕОДОБРЕНИЕ ИММИГРАЦИИ В ОБЩЕСТВЕ}

Негативное отношение избирателей к иммиграции, как было показано выше, во многом объясняет электоральную поддержку правых националистических партий. Вполне естественным является предположение, что широкое распространение такого неприязненного отношения в обществе выступает дополнительным катализатором для избирателей РПП, нормативно оправдывая нетерпимость и поддержку политических персонажей с небезупречной репутацией. С результатами анализа, направленного на прояснение этого вопроса, можно познакомиться, обратившись к модели С в таблице 3. Она описывает двухуровневую логистическую модель, в которой к переменным индивидуального уровня, характеризующим социальную демографию и антииммигрантские убеждения, добавляется контекстуальный фактор, указывающий на преобладающие в обществе представления о последствиях иммиграции, а также межуровневая интеракция между двумя показателей отношения к иммиграции.

Изучавшиеся страны очень сильно отличаются преобладающими в общественном мнении взглядами по вопросу вредности или нужности иммиграции (средние значения индивидуальных позиций). При низких значениях нашего агрегированного показателя, которые можно обнаружить во многих посткоммунистических государствах, преобладающее большинство избирателей считает, что иммиграция несет угрозы экономике и культуре, делает жизнь менее комфортной, тогда как его высокие значения, характеризующие, как правило, наиболее развитые европейские демократии, указывают на уверенность большинства граждан в ее положительных последствиях.

Согласно коэффициентам в модели С, антииммигрантские мотивации голосования за правых радикалов действительно зависят от того, как большинство в обществе относится к приезжим. Однако зависимость оказалась прямо противоположной той, какую мы предполагали увидеть, - противники иммиграции с большей вероятностью отдавали 
свои голоса правым радикалам не там, где их поддерживало общественное мнение, во многих странах Восточной Европы. Это происходило, напротив, в тех обществах, большинство в которых полагало, что иммиграция нужна и приносит положительные плоды. В их число входят Скандинавские страны и другие развитые государства Западной Европы. В то же время нужно заметить, что влияние контекстуального фактора, измеряющего отношение в обществе к иммиграции, на антииммигрантское голосование за РПП было не очень сильным, хотя и статистически значимым. (Этот фактор объясняет лишь около 30 \% дисперсии, говорящей о неодинаковых зависимостях в европейских странах между индивидуальной переменной неприятия иммиграции и поддержкой радикальных партий, причем модерация становится статистически незначимой при добавлении в модель дихотомии Западная/Восточная Европа, с которой данный фактор, как отмечалось выше, тесно связан.)

Наши результаты можно рассматривать в качестве подтверждения теоретических соображений, объясняющих подъем РПП в развитых странах Европы мобилизацией националистически настроенного и глубоко консервативного меньшинства в ответ на фундаментальные либеральные культурные изменения, происходившие в них по мере постмодернизации.

\section{МОДЕРАЦИИ АНТИИММИГРАНТСКОГО ГОЛОСОВАНИЯ ЗА РПП КОНТЕКСТУАЛЬНЫМИ ФАКТОРАМИ}

Проверка предположений о стимулирующем влиянии общественного контекста на поддержку РПП сторонниками антииммигрантских воззрений проводилась первоначально с помощью двухуровневого логистического моделирования, в котором голосование за эти партии объясняется на индивидуальном уровне отношением респондентов к иммиграции (при контроле социальной демографии), на уровне стран - одним из описанных ранее контекстуальных факторов, которые включались в уравнения по-отдельности, а также межуровневой интеракцией между отношением к иммиграции и соответствующим фактором. Основные результаты этого анализа собраны в таблице 4. Каждая модель, связанная с тем или иным фактором различий между странами, описывается в ней двумя коэффициентами Odds Ratios (остальные фиксированные и случайные эффекты опущены). Один из них, OR1, 
говорит о том, насколько отличаются доли голосов за РПП в странах с неодинаковыми значениями контекстуального фактора (при его изменении на одно стандартное отклонение и среднем значении переменной отношения к иммиграции). В центре нашего внимания будет другой коэффициент, $O R 2,-$ он характеризует интеракцию переменной антииммигрантских убеждений с соответствующим фактором контекста и показывает, как его изменение (на стандартное отклонение) сказывается на стимулирующем действии этих убеждений, ведущем к поддержке РПП (значения $O R$, превышающие единицу, говорят об усилении эффекта, а те, что меньше единицы, - об его ослаблении).

Согласно приведенным в таблице 4 значениям коэффициента для интересующей нас интеракции, в странах Западной Европы, как уже было показано, антииммигрантские воззрения играют намного более важную роль, побуждая избирателей отдать свои голоса за правых националистов, чем в посткоммунистических государствах. Ряд экономических факторов также создает благоприятные условия для антииммигрантского голосования. Такие условия появляются в наиболее экономически развитых странах Европы с высоким ВВП, при изменении структуры занятости в экономике в постиндустриальном направлении, предполагающем расширение сектора услуг, и низких доходных неравенствах по Джини-индексу. Все эти факторы тесно взаимосвязаны, а выявленные зависимости хорошо вписываются в теоретические представлениями о влиянии постмодернизации на пробуждение электорального меньшинства, голосующего за РПП.

Эффекты, обнаруженные при рассмотрении социального государства, не поддерживают предположения о сокращении поддержки РПП, происходящей при щедрой компенсации государством трудностей, связанных с низким общественным положением, и сглаживании при этом конфликта с приезжими из-за ограниченных ресурсов. Напротив, с увеличением государственных расходов на социальную защиту побудительная сила антииммигрантских убеждений становится все более отчетливой. Этот факт согласуется с тезисом о том, что голосование за правых националистов может вызываться нетерпимостью к иммигрантам со стороны людей с невысоким общественным положением, порождаемой нежеланием делиться социальными благами, которые они получают от государства (так называемый welfare chauvinism).

Получают эмпирическое обоснование и теоретические положения о важной роли масштабов иммиграции, измеренной долями родив- 
шихся в других государствах или темпов прироста такого населения. В тех странах, где было особенно много иммигрантов и где их число быстро увеличивалось в 2010-е годы, негативное отношение к этому процессу особенно заметно подталкивало избирателей отдать свои голоса радикальным правым партиям. Как и предполагалось, состояние преступности, о котором мы судили по распространенности воровства и случаям посягательств на членов семьи участников опросов, тоже следует учитывать среди факторов, способствующих электоральной поддержке РПП со стороны недовольных иммиграцией - с ростом этих показателей такая поддержка усиливается.

Таблица 4

Контексты электоральных успехов РПП и антииммигрантских мотиваций их поддержки в странах Европы

\begin{tabular}{|c|c|c|c|}
\hline ФАКТОРЫ & $\begin{array}{l}\text { OR1 } \\
\text { OR2 }\end{array}$ & ФАКТОРЫ & $\begin{array}{l}\text { OR1 } \\
\text { OR2 }\end{array}$ \\
\hline ЕВРОПА & & ПАРТИЙНАЯ СИСТЕМА & \\
\hline Восточная / Западная & $\begin{array}{l}0.83 \\
49.84^{* * *}\end{array}$ & $\begin{array}{l}\text { Действительное число } \\
\text { партий }\end{array}$ & $\begin{array}{l}1.28 \\
1.58\end{array}$ \\
\hline $\begin{array}{l}\text { ЭКОНОМИКА, } \\
\text { НЕРАВЕНСТВА }\end{array}$ & & \begin{tabular}{|l|} 
Позиция основной \\
правой партии в культур- \\
ном измерении (национа- \\
лизм) \\
\end{tabular} & $\begin{array}{l}2.77^{* *} \\
1.42\end{array}$ \\
\hline ВВП (на душу) & $\begin{array}{l}1.10 \\
6.90^{* * *}\end{array}$ & \begin{tabular}{|l} 
Позиция системы \\
в культурном измерении \\
(национализм)
\end{tabular} & $\begin{array}{l}3.05^{* * *} \\
1.37\end{array}$ \\
\hline Безработные (доля) & $\begin{array}{l}0.41^{* *} \\
0.44\end{array}$ & $\begin{array}{l}\text { Значимость в экономиче- } \\
\text { ском измерении } \\
\text { (либерализм) (a) }\end{array}$ & $\begin{array}{l}0.99 \\
1.23\end{array}$ \\
\hline Джини-индекс & $\begin{array}{l}0.93 \\
0.28^{* *}\end{array}$ & \begin{tabular}{|l|} 
Значимость в культурном \\
измерении \\
(национализм) (b) \\
\end{tabular} & $\begin{array}{l}2.25^{*} \\
2.77^{*}\end{array}$ \\
\hline Сектор услуг (доля) & $\begin{array}{l}0.69 \\
3.88^{\star \star *}\end{array}$ & $\begin{array}{l}\text { Отношение экономиче- } \\
\text { ской и культурной } \\
\text { значимостей (a)/(b) } \\
\end{array}$ & $\begin{array}{l}0.41^{*} \\
0.58\end{array}$ \\
\hline СОЦИАЛЬНОЕ ГОСУДАРСТВО & & $\begin{array}{l}\text { Поляризация в экономи- } \\
\text { ческом измерении (c) }\end{array}$ & $\begin{array}{l}1.17 \\
3.60^{* * *}\end{array}$ \\
\hline $\begin{array}{l}\text { Госрасходы на социальную } \\
\text { защиту (на душу) }\end{array}$ & $\begin{array}{l}1.29 \\
7.43^{\star * *}\end{array}$ & $\begin{array}{l}\text { Поляризация в культур- } \\
\text { ном измерении (d) }\end{array}$ & $\begin{array}{l}2.81^{* *} \\
2.14\end{array}$ \\
\hline
\end{tabular}


Окончание таблицы 4

\begin{tabular}{|c|c|c|c|}
\hline ФАКТОРЫ & $\begin{array}{l}\text { OR1 } \\
\text { OR2 }\end{array}$ & ФАКТОРЫ & $\begin{array}{l}\text { OR1 } \\
\text { OR2 }\end{array}$ \\
\hline ИММИГРАЦИЯ & & $\begin{array}{l}\text { Отношение экономиче- } \\
\text { ской и культурной } \\
\text { поляризаций }(\mathrm{c}) /(\mathrm{d})\end{array}$ & $\begin{array}{l}0.28^{\star * *} \\
0.92\end{array}$ \\
\hline Иммигранты (доля) & $\begin{array}{l}0.89 \\
4.81^{\star * *}\end{array}$ & $\begin{array}{l}\text { Позиция РПП в культур- } \\
\text { ном измерении (нацио- } \\
\text { нализм) }\end{array}$ & $\begin{array}{l}1.28 \\
2.08\end{array}$ \\
\hline $\begin{array}{l}\text { Прирост иммигрантов } \\
\text { (процент) }\end{array}$ & $\begin{array}{l}1.79^{*} \\
4.39^{\star}\end{array}$ & $\begin{array}{l}\text { КУЛЬТУРНЫЕ } \\
\text { ЦЕННОСТИ, }\end{array}$ & \\
\hline ПРЕСТУПНОСТЬ & & $\begin{array}{l}\text { Устранение тревоги / } \\
\text { Развитие }\end{array}$ & $\begin{array}{l}0.87 \\
6.62^{\star * *}\end{array}$ \\
\hline $\begin{array}{l}\text { Нападение на близких людей } \\
\text { (доля) }\end{array}$ & $\begin{array}{l}0.86 \\
4.40^{\star * *}\end{array}$ & ПОСТМОДЕРНИЗАЦИЯ & \\
\hline Воровство на 100 тыс. & $\begin{array}{l}1.51 \\
5.97^{\star * *}\end{array}$ & $\begin{array}{l}\text { Индекс постиндустриаль- } \\
\text { ного развития }\end{array}$ & $\begin{array}{l}0.96 \\
7.63^{\star * *}\end{array}$ \\
\hline
\end{tabular}

Двухуровневые логистические модели, фиксирующие воздействие каждого отдельно взятого контекстуального фактора (при изменении на 1 стандартное отклонение) на голосование за РПП - OR1 (Odds Ratio 1) (при среднем значении индекса отношения к иммиграции), и на интеракции между антииммигрантскими убеждениями и голосованием за РПП - OR2 (Odds Ratio 2) (при контроле пола, возраста и образования). Уровни значимости регрессионных коэффициентов: ${ }^{\star * \star} 0.001,{ }^{* *} 0.01,{ }^{\star} 0.05$. N1 (респонденты) $=25702$; N2 (страны) $=28$.

Полученные результаты не позволяют говорить об изменении антииммигрантских эффектов в различных партийных системах европейских стран - почти все интеракции антииммигрантских взглядов с признаками, которые описывают партии и партийные системы, оказались статистически незначимыми, за двумя исключениями. Слабая, но удовлетворяющая общепринятым статистическим критериям, интеракция обнаруживается с фактором значимости для партийной системы социокультурного измерения политического конфликта. Там, где партии придают этому конфликту большее значение, повышается вероятность того, что избиратели, не приемлющие иммиграции, проголосуют за правых радикалов. Другой контекстуальный фактор, вызывающий анало- 
гичный эффект, но гораздо более отчетливый, - это поляризация партий в экономическом измерении, однако это связано с тем, что такая поляризация была выше в развитых западных странах, чем в Восточной Европе (при дополнительном контроле на втором уровне фактора постмодернизации эффект становится статистически несущественным).

В то же время при многоуровневом моделировании получают подкрепление закономерности, описанные ранее, когда рассматривались корреляции между долями голосов за РПП и контекстуальными факторами (теперь на них указывают коэффициенты OR1). Так, электоральным успехам правых радикалов способствуют идеологический сдвиг основной правой партии и партийной системы в целом в направлении консервативного национализма, легитимирующие РПП, а также растущая важность для партий социокультурного измерения политического противостояния и их более резкая поляризация в этом измерении.

Еще одним существенным условием усиления воздействия антииммигрантской мотивации на голосование за РПП является культура ценностные акцентуации в обществе, указывающие на распространение устремлений к личностному росту. В странах, где для многих людей важно устранение тревоги, такой стимуляции не наблюдается. Подобная зависимость может быть истолкована в рамках теории ответной реакции на либеральные изменения культуры в процессе постмодернизации.

Культурные ценности, как отмечалось в разделе, посвященном методологии исследования, тесно связаны с рядом контекстуальных факторов, характеризующих общественные изменения в постиндустриальном направлении. При этом все они - высокий ВВП, значительная занятость в секторе услуг, большие расходы бюджета на социальную защиту и культура личностного роста - представляют, как только что было показано, ряд аспектов общественного контекста, способствующего антииммигрантскому голосованию за правых националистов. Вероятно, за всеми такими отдельными эффектами стоит объединяющее их общее качество - постмодернизационное изменение общества. Действительно, как можно видеть в таблице 4, с повышением значений индекса постиндустриального развития происходит усиление зависимости между переменной антииммигрантских убеждений избирателей и голосованием за РПП, причем коэффициент для соответствующей интеракции оказался заметно выше, чем в уравнениях с отдельными факторами постмодернизации, а сам индекс лучше, чем любой из составляющих его факторов, объясняет дисперсию этой зависимости в разных странах (74 \%). 


\section{ГЛАВНЫЕ МОДЕРАТОРЫ ВЛИЯНИЯ АНТИИММИГРАНТСКИХ УБЕЖДЕНИЙ НА ПОДДЕРЖКУ ПРАВЫХ РАДИКАЛОВ}

На следующем этапе построения двухуровневых моделей нам предстоит выделить из представленных факторов второго уровня те, которые играют наиболее важную роль, определяя различия стран Европы по числу голосующих за радикальные правые партии и по влиянию на голосование за эти партии антииммигрантских воззрений. Для этого на втором уровне в уравнения включались одновременно несколько факторов контекста и учитывались интеракции каждого из них с индивидуальной переменной отношения к иммиграции. С основными результатами такого моделирования можно познакомиться в таблице 5, в которой приводятся уже знакомые нам коэффициенты OR1 и OR2 (соответственно объяснение контекстуальными факторами различий в доле голосующих за правых радикалов и неодинакового влияния на голосование за эти партии антииммигрантских убеждений).

В число объяснительных факторов контекста в модели 1 были включены показатели безработицы, иммиграции, темпов ее изменения, распространения воровства и действительного числа партий. Именно этим структурным факторам были посвящены многие исследования, так и не приведшие аналитиков к согласию относительно их значения для успехов РПП. Наши результаты говорят о том, что все они важны, определяя условия для стимуляции антииммигрантских убеждений. Эти убеждения побуждают к голосованию за правых радикалов прежде всего в странах со значительной долей иммигрантов и быстрым их приростом, а также при высоких уровнях нетяжких преступлений и безработицы, в многопартийных системах. Однако, кроме коэффициентов, относящихся к масштабам иммиграции, остальные три зависимости были достаточно слабыми, хотя и значимыми со статистической точки зрения.

Уравнение модели 2 дополнительно включало индекс постиндустриального развития и его интеракцию на переменную отношения индивидов к иммиграции. С ростом его значений происходит усиление влияния антииммигрантских убеждений на голосование за РПП. При этом слабые зависимости, отмеченные при обсуждении модели 1 (с показателями безработицы, воровства, числа партий), становятся статистически незначимыми. 
Таблица 5

Влияние контекстуальных факторов на голосование за РПП и на его антииммигрантские мотивации

\begin{tabular}{|c|c|c|c|c|c|c|}
\hline \multirow{2}{*}{ ФАКТОРЫ } & \multicolumn{2}{|c|}{ Модель 1} & \multicolumn{2}{|c|}{ Модель 2} & \multicolumn{2}{|c|}{ Модель 3} \\
\hline & OR1 & OR2 & OR1 & OR2 & OR1 & OR2 \\
\hline Безработные, доля & $0.46^{*}$ & $1.52^{*}$ & 0.56 & 1.42 & & \\
\hline Иммигранты, доля & 0.80 & $4.46^{* * *}$ & 1.25 & $3.16^{\star *}$ & 1.05 & $2.81^{\star *}$ \\
\hline Рост доли иммигрантов & 1.20 & $3.79^{* *}$ & 1.55 & $3.15^{\star *}$ & 1.28 & $2.79^{\star *}$ \\
\hline Воровство на 100 тыс. & 1.14 & $1.67^{\star}$ & 1.93 & 1.02 & & \\
\hline $\begin{array}{l}\text { Действительное число } \\
\text { партий }\end{array}$ & 1.07 & $1.40^{*}$ & 1.23 & 1.23 & & \\
\hline $\begin{array}{l}\text { Индекс постиндустриаль- } \\
\text { ного развития }\end{array}$ & & & 0.36 & $2.41^{\star}$ & 0.99 & $2.78^{\star *}$ \\
\hline $\begin{array}{l}\text { Позиция основной правой } \\
\text { партии (национализм) }\end{array}$ & & & & & $1.75^{\star}$ & 1.05 \\
\hline $\begin{array}{l}\text { Отношение экономической } \\
\text { и культурной поляризаций }\end{array}$ & & & & & $0.40^{*}$ & 0.97 \\
\hline
\end{tabular}

Двухуровневые логистические модели, свидетельствующие о совместном влиянии контекстуальных факторов (при изменении на 1 стандартное отклонение) на голосование за РПП - OR1 (Odds Ratio 1) (при среднем значении индекса отношения к иммиграции), и на интеракции между антииммигрантскими убеждениями и голосованием за РПП - OR2 (Odds Ratio 2) (при контроле пола, возраста и образования). Уровни значимости регрессионных коэффициентов: ${ }^{* *} 0.001,{ }^{* *} 0.01,{ }^{*} 0.05$. N1 $($ респонденты $)=25702 ; \mathrm{N} 2($ страны $)=28$.

Наконец, в модели 3 были опущены несущественные факторы и добавлены показатели, характеризующие идеологическую позицию основной правой партии в культурном измерении и соотношение экономической и культурной поляризаций. Как и следовало ожидать, учитывая предшествующий анализ, оба эти показателя объясняют только неодинаковую численность голосующих за правые националистические партии в разных странах - она растет при смещении правой системной партии к полюсу национализма, а также там, где отчетливо 
выражена культурная поляризация партий. Факторы масштабов иммиграции и постиндустриализации продолжают определять условия для антииммигрантского голосования за РПП. Характер зависимостей, которые свидетельствуют о модерациях, зафиксированных в третьей модели, иллюстрирует рисунок 1, построенный по ее уравнению.



a

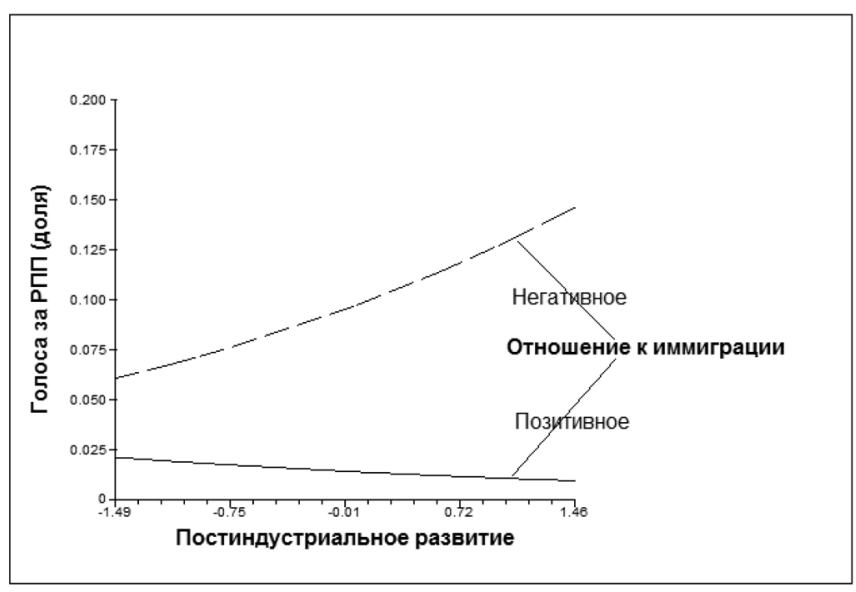

6

Рис. 1. Контексты антииммигрантской мотивации голосования за РПП а) масштабы иммиграции; б) постмодернизация

Рисунки построены по уравнению модели 3 (при средних значениях контролируемых переменных), негативное и позитивное отношение к иммиграции - средние значения в нижнем и верхнем квартилях 
С увеличением в стране численности иммигрантов, как видно на рисунке 1a, избиратели с негативным отношением к иммиграции оказываются особенно склонными к голосованию за правых радикалов. Сходный рисунок получится, если вместо фактора численности иммигрантского населения использовать показатель его прироста (не приводится). Согласно рисунку 16, вероятность электоральной поддержки этих партий со стороны избирателей, недовольных иммиграцией, заметно повышается по мере развития стран в постиндустриальном направлении.

Таким образом, анализ показывает, что влияние антииммигрантских убеждений на поддержку при выборах парламента радикальных правых партий зависит от общественного контекста. Оно усиливается многими факторами, важнейшими среди которых являются численность в стране приезжих, темпы ее прироста, а также общественные изменения, связанные с постмодернизацией.

\section{ЗАКЛЮЧЕНИЕ}

Представленная работа посвящена анализу общественных условий, способствующих в странах Западной и Восточной Европы успехам на парламентских выборах радикальных правых партий. В многочисленных исследованиях, которые рассматривали эту проблему главным образом в Западной Европе, отмечалось значение таких структурных, институциональных и политических факторов, как безработица, иммигрантское население, рост преступности, многопартийность, пропорциональность представительства и централизация политической системы, близость к центру основной правой партии в идеологическом размежевании, сходство идеологических позиций ведущих правых и левых партий, значимость и поляризация партийной системы в социокультурном измерении по отношению к экономическому измерению (и некоторых других различий между странами). Однако полученные результаты нередко не согласуются друг с другом, что не позволяет с уверенностью говорить о том, какие именно общественные факторы оказываются благоприятными для повышения электоральной поддержки правых радикалов. Одно из перспективных направлений в этих исследованиях связано с анализом общественных условий, усиливающих готовность сторонников правых радикалов отдать свои голоса на выборах за РПП. 
Предпринятое исследование, в котором использовались опросные данные Европейского социального исследования (ESS, Rounds 8-9, 28 стран) и целый ряд контекстуальных факторов, характеризующих отличия между странами Западной и Восточной Европы по состоянию экономики, иммигрантского населения, преступности, партийных систем и культуры, был нацелен на изучение - после европейского миграционного кризиса - воздействия этих факторов на зависимость голосования за РПП от антииммигрантских взглядов участников опросов.

Двухуровневое моделирование позволило, в согласии полученными ранее выводами, установить, что негативное отношение опрошенных к иммиграции (ее последствиям для экономики, культуры, образа жизни) является важнейшей причиной их электоральной поддержки радикальных националистических партий. Эта зависимость особенно отчетливо проявляется в Западных странах, но ее можно обнаружить и в Восточной Европе.

Структурные, институциональные и культурные факторы лишь очень слабо связаны с неодинаковыми показателями успеха этих партий в изучавшихся странах. Наиболее отчетливые зависимости обнаруживаются при рассмотрении партийных систем. Установлено, что больших достижений правым радикалам удается добиться в том случае, когда их призывы получают легитимацию в политике благодаря смещению в консервативно-националистическом направлении основной правой партии или партийной системы в целом. Их успехам способствуют также высокая значимость социокультурных проблем в партийной системе и сильная поляризации партийных позиций по этим проблемам, а также повышение культурной значимости и поляризации по отношению к соответствующим экономическим показателям.

Целый ряд контекстуальных факторов выступают модераторами зависимости между антииммигрантскими убеждениями опрошенных и голосованием за РПП. Индивиды, придерживающиеся этих убеждений, отдают свои голоса радикальным партиям особенно охотно, когда в стране живет много иммигрантов или их число быстро растет. Еще одно важное условие - продвижение общества по траектории постиндустриального развития. Антииммигрантские мотивации голосования за националистические партии усиливаются с повышением экономического благосостояния, расширением сектора услуг, укреплением социального государства и при ценностном сдвиге в культуре от ориентаций на устранение тревоги к личностному развитию. 
Эмпирические обобщения, полученные в исследовании, уточняют теоретические положения, объясняющие, почему при определенных общественных условиях избиратели склонны отдавать свои голоса на парламентских выборах радикальным правым партиям. Анализ этих условий требует внимательного изучения эффектов модерации, характеризующих воздействие контекстуальных общественных факторов на социально-структурные и аттитюдные детерминации голосования за эти партии.

\section{Литература/References}

Allen T.J. All in the party family? Comparing far right voters in Western and Post-Communist Europe, Party Politics, 2017, 23(3), pp. 274-285. doi: $10.1177 / 1354068815593457$.

Amengay A., Stockemer D. The Radical Right in Western Europe: A MetaAnalysis of Structural Factors, Political Studies Review, 2019, 17(1), pp. 30-40. doi: 10.1177/1478929918777975.

Arzheimer K. Contextual Factors and the Extreme Right Vote in Western Europe, 1980-2002, American Journal of Political Science, 2009, 53(2), pp. 259-275. doi: 10.1111/j.1540-5907.2009.00369.x.

Arzheimer K. Explaining Electoral Support for the Radical Right, The Oxford Handbook of the Radical Right. Ed. by J. Rydgren. New York: Oxford University Press, 2018, pp. 143-165. doi: 10.1093/oxfordhb/9780190274559.013.8.

Arzheimer K., Carter E. Political Opportunity Structures and Right-Wing Extremist Party Success, European Journal of Political Research, 2006, 45(3), pp. 419443. doi: 10.1111/j.1475-6765.2006.00304.x.

Betz H-G. The Two Faces of Radical Right-Wing Populism in Western Europe, The Review of Politics, 1993, 55(4), pp. 663-686. doi: 10.1017/S0034670500018040.

Bornschier S. Globalization, Cleavages, and the Radical Right In: The Oxford Handbook of the Radical Right. Ed. by J. Rydgren. New York: Oxford University Press, 2018, pp. 212-238. doi: 10.1093/oxfordhb/9780190274559.013.11.

Brils T., Muis J., Gaidyte T. Dissecting Electoral Support for the Far Right: A Comparison between Mature and Post-Communist European Democracies, Government and Opposition, 2020, pp. 1-28. doi:10.1017/gov.2020.17.

Bustikova L. Revenge of the Radical Right, Comparative Political Studies, 2014, 47(12), pp. 1738-1765. doi: 10.1177/0010414013516069.

Buštíková L. The Radical Right in Eastern Europe. In: The Oxford Handbook of the Radical Right. Ed. by J. Rydgren. New York: Oxford University Press, 2018, pp. 565-582. doi: 10.1093/oxfordhb/9780190274559.013.28.

Carter E.L. Proportional Representation and the Fortunes of Right-Wing Extremist Parties, West European Politics, 2002, 25(3), pp. 125-146. doi: 10.1080/713601617. 
Carter E. The Extreme Right in Western Europe: Success or Failure? Manchester and New York: Manchester University Press, 2005, 288 p.

Dalton R.J. The Quantity and the Quality of Party Systems: Party System Polarization, Its Measurement, and Its Consequences, Comparative Political Studies, 2008, 41(7), pp. 899-920. doi: 10.1177/0010414008315860.

Dinas E., van Spanje J. Crime Story: The Role of Crime and Immigration in the Anti-Immigration Vote, Electoral Studies, 2011, 30(4), pp. 658-671. doi: 10.1016/j. electstud.2011.06.010.

ESS Round 9: European Social Survey Round 9 Data. Data file edition 3.1. NSD Norwegian Centre for Research Data, Norway - Data Archive and distributor of ESS data for ESS ERIC, 2018. doi: 10.21338/NSD-ESS9-2018.

ESS Round 8: European Social Survey Round 8 Data. Data file edition 2.2. NSD Norwegian Centre for Research Data, Norway - Data Archive and distributor of ESS data for ESS ERIC, 2016. doi: 10.21338/NSD-ESS8-2016.

Georgiadou V., Rori L., Roumanias C. Mapping the European far right in the 21st century: A meso-level analysis, Electoral Studies, 2018, 54, pp. 103-115. doi: 10.1016/j.electstud.2018.05.004.

Givens T.E. The Role of Socioeconomic Variables in the Success of Radical Right Parties. In: Shadows over Europe: The Development and Impact of the Extreme Right in Western Europe. Ed. by M. Schain, A. Zolberg, P. Hossay. New York: Palgrave Macmillan, 2002, pp. 137-158.

Golder M. Electoral Institutions, Unemployment and Extreme Right Parties: A Correction, British Journal of Political Science, 2003, 33(3), pp. 525-534. doi: $10.1017 /$ S0007123403220226.

Golder M. Far Right Parties in Europe, Annual Review of Political Science, 2016, 19, pp. P. 477-497. doi: 10.1146/annurev-polisci-042814-012441.

Halikiopoulou D., Vlandas T. When economic and cultural interests align: The anti-immigration voter coalitions driving far right party success in Europe, European Political Science Review, 2020, 12(4), pp. 427-448. doi: 10.1017/S175577392000020X.

Ignazi P. The Silent Counter-Revolution. Hypotheses on the Emergence of Extreme Right-Wing Parties in Europe, European Journal of Political Research, 1992, 22(1), pp. 3-34. doi: 10.1111/j.1475-6765.1992.tb00303.x.

ILO World Social Protection Report 2017-19: Universal social protection to achieve the Sustainable Development Goals. International Labour Office - Geneva: ILO, 2017. URL: http://ilo.org/wcmsp5/groups/public/-dgreports/-dcomm/-publ/documents/ publication/wcms_604882.pdf (accessed: 07.10.2021).

Immerzeel T., Lubbers M., Coffé H. Competing with the radical right: Distances between the European radical right and other parties on typical radical right issues, Party Politics, 2016, 22(6), pp. 823-834. doi: 10.1177/1354068814567975.

Inglehart R. The Silent Revolution: Changing Values and Political Styles among Western Publics. Princeton, New Jersey: Princeton University Press, 1977. 495 p. doi: 10.1515/9781400869589. 
Inglehart R. Culture Shift in Advanced Industrial Society. Princeton, New Jersey: Princeton University Press, 1990. 504 p. doi: 10.2307/j.ctv346rbz.

Inglehart R. Modernization and Postmodernization: Cultural, Economic, and Political Change in 43 Societies. Princeton, New Jersey: Princeton University Press, 1997. 464 p. doi: 10.2307/j.ctv10vm2ns.

Jackman R.W., Volpert K. Conditions Favouring Parties of the Extreme Right in Western Europe, British Journal of Political Science, 1996, 26(4), pp. 501-521.

Kessler A.E., Freeman G.P. Support for Extreme Right-Wing Parties in Western Europe: Individual Attributes, Political Attitudes, and National Context, Comparative European Politics, 2005, 3(3), pp. 261-288. doi: 10.1057/palgrave.cep.6110063.

Kitschelt H. Growth and Persistence of the Radical Right in Postindustrial Democracies: Advances and Challenges in Comparative Research, West European Politics, 2007, 30(5), pp. 1176-1206. doi: 10.1080/01402380701617563.

Kitschelt H. Party Systems and Radical Right-Wing Parties. In: The Oxford Handbook of the Radical Right. Ed. by J. Rydgren. New York: Oxford University Press, 2018, pp. 166-199. doi: 10.1093/oxfordhb/9780190274559.013.9.

Kitschelt $\mathrm{H}$., in collaboration with McGann A.J. The radical right in Western Europe: a comparative analysis. Ann Arbor, MI: University of Michigan Press, 1995. xiii, 332 p. doi: 10.3998/mpub.14501.

Knigge P. The Ecological Correlates of Right-Wing Extremism in Western Europe, European Journal of Political Research, 1998, 34(2), pp. 249-279. doi: 10.1023/A:1006953714624.

Laakso M., Taagepera R. "Effective" Number of Parties: A Measure with Application to West Europe, Comparative Political Studies, 1979, 12(1), pp. 3-27. doi: 10.1177/001041407901200101.

Lubbers M., Coenders M. Nationalistic attitudes and voting for the radical right in Europe, European Union Politics, 2017, 18(1), pp. 98-118. doi: $10.1177 / 1465116516678932$.

Lubbers M., Gijsberts M., Scheepers P. Extreme Right-Wing Voting in Western Europe, European Journal of Political Research, 2002, 41(3), pp. 345-378. doi: $10.1111 / 1475-6765.00015$

Meguid B.M. Competition between Unequals: The Role of Mainstream Party Strategy in Niche Party Success, American Political Science Review, 2005, 99(3), pp. 347-359. doi: 10.1017/S0003055405051701.

Minkenberg M., Kossack O. Conclusions: Actors, interaction, and impact in comparison. In: Transforming the Transformation? The East European radical right in the political process. Ed. by M. Minkenberg. London and New York: Routledge, 2015, pp. 349-359. doi: 10.4324/9781315730578.

Mudde C. Populist Radical Right Parties in Europe. Cambridge: Cambridge University Press, 2007. 404 p. doi: 10.1017/CBO9780511492037.

Mudde C. The Study of Populist Radical Right Parties: Towards a Fourth Wave, C-REX Working Paper Series, 2016, 1, pp. 1-23. 
Muis J., Immerzeel T. Causes and consequences of the rise of populist radical right parties and movements in Europe, Current Sociology Review, 2017, 65(6), pp. 909-930. doi: 10.1177/0011392117717294.

Norris P. Radical Right: Voters and Parties in the Electoral Market, New York: Cambridge University Press, 2005. 363 p. doi: 10.1017/CBO9780511615955.

Norris P., Inglehart R. Cultural Backlash: Trump, Brexit, and Authoritarian Populism, New York: Cambridge University Press, 2019, pp. 564. doi: 10.1017/9781108595841.

Pytlas B. Radical Right Parties in Central and Eastern Europe: Mainstream Party Competition and Electoral Fortune. London, New York: Routledge, 2016. 242 p.

Raudenbush S.W., Bryk A.S. Hierarchical Linear Models: Applications and Data Analysis Methods. Thousand Oaks, CA: Sage, 2002. 512 p.

Rydgren J. The Sociology of the Radical Right, Annual Review of Sociology, 2007, 33, pp. 241-262. doi: 10.1146/annurev.soc.33.040406.131752.

Rydgren J. The Radical Right: An Introduction. In: The Oxford Handbook of the Radical Right. Ed. by J. Rydgren. New York: Oxford University Press, 2018, pp. 1-16. doi: 10.1093/oxfordhb/9780190274559.013.1.

Safronov V.V. Golosovaniye za radikal'nyye pravyye partii v Yevrope: rol' kul'turnogo izmeneniya i partiynoy polyarizatsii (Chast' 2) [Voting for Radical Right Parties in Europe: The Role of Cultural Change and Party Polarization (Part 2)], Teleskop: zhurnal sotsiologicheskikh $i$ marketingovykh issledovaniy [Telescope: Journal of Sociological and Marketing Research], 2019, 1, pp. 2-11. doi: 10.33491/telescope2019.101. (In Russian)

Schwartz S.H. Universals in the content and structure of values: Theoretical advances and empirical tests in 20 countries, Advances in experimental social psychology, 1992, 25, pp. 1-65. doi: 10.1016/S0065-2601(08)60281-6.

Schwartz S. European Social Survey Core Questionnaire Development. A Proposal for Measuring Value Orientations across Nations (Chapter 7). London: European Social Survey, City University London, 2001.

Schwartz S.H. A Theory of Cultural Value Orientations: Explication and Applications, Comparative Sociology, 2006, 5(2-3), pp. 137-182. doi: 10.1163/ 156913306778667357.

Schwartz S.H. An Overview of the Schwartz Theory of Basic Values, Online Readings in Psychology and Culture, 2012, 2(1). doi: 10.9707/230770919.1116.

Sigelman L., Yough S.N. Left-Right Polarization in National Party Systems: A Cross-National Analysis, Comparative Political Studies, 1978, 11(3), pp. 335-379. doi: 10.1177/001041407801100304.

Smith J.M. Does Crime Pay? Issue Ownership, Political Opportunity, and the Populist Right in Western Europe, Comparative Political Studies, 2010, 43(11), pp. 1471-1498. doi: 10.1177/0010414010372593.

Spies D. Explaining Working-Class Support for Extreme Right Parties: A Party Competition Approach, Acta Politica, 2013, 48(3), pp. 296-325. doi: 10.1057/ ap.2012.37. 
Spies D., Franzmann S.T. A Two-Dimensional Approach to the Political Opportunity Structure of Extreme Right Parties in Western Europe, West European Politics, 2011, 34(5), pp. 1044-1069. doi: 10.1080/01402382.2011.591096.

Stefanovic D., Evans G. Multiple Winning Formulae? Far Right Voters and Parties in Eastern Europe, Europe-Asia Studies, 2019, 71(9), pp. 1443-1473. doi: 10.1080/09668136.2019.1653447.

Stockemer D., Halikiopoulou D., Vlandas T. 'Birds of a feather'? Assessing the prevalence of anti-immigration attitudes among the far right electorate, Journal of Ethnic and Migration Studies, 2020, pp. 1-27. doi: 10.1080/1369183X.2020.1770063.

Stockemer D., Lentz T., Mayer D. Individual Predictors of the Radical Right-Wing Vote in Europe: A Meta-Analysis of Articles in Peer-Reviewed Journals 1995-2016, Government and Opposition, 2018, 53(3), pp. 569-593. doi: 10.1017/gov.2018.2.

Swank D., Betz H-G. Globalization, the Welfare State and Right-Wing Populism in Western Europe, Socio-Economic Review, 2003, 1(2), pp. 215-245. doi: 10.1093/ soceco/1.2.215.

Teorell J., Dahlberg S., Holmberg S., Rothstein B., Pachon N.A., Axelsson S. The Quality of Government Standard Dataset, version Jan20. University of Gothenburg: The Quality of Government Institute, 2020. URL: http://www.qog.pol.gu.se (accessed 05.10.2021). doi: 10.18157/qogstdjan20.

The Oxford Handbook of the Radical Right. Ed. by J. Rydgren. New York: Oxford University Press, 2018. 760 p. doi: 10.1093/oxfordhb/9780190274559.001.0001.

United Nations, Department of Economic and Social Affairs. Population Division. Trends in International Migrant Stock: The 2017 revision (United Nations database, POP/DB/MIG/Stock/Rev.2017), 2017.

Van der Brug W., Fennema M., Tillie J. Why Some Anti-Immigrant Parties Fail and Others Succeed. A Two-Step Model of Aggregate Electoral Support, Comparative Political Studies, 2005, 38(5), pp. 537-573. doi: 10.1177/0010414004273928.

Veugelers J., Magnan A. Conditions of Far-Right Strength in Contemporary Western Europe: An Application of Kitschelt's Theory, European Journal of Political Research, 2005, 44(6), pp. 837-860. doi:10.1111/j.1475-6765.2005.00249.x.

Vlandas T., Halikiopoulou D. Welfare state policies and far right party support: moderating 'insecurity effects' among different social groups, West European Politics, 2021, pp. 1-26. doi: 10.1080/01402382.2021.1886498

Volkens A., Burst T., Krause W., Lehmann P., Matthieß T., Merz N., Regel S., Weßels B., Zehnter L. The Manifesto Data Collection. Manifesto Project (MRG / CMP / MARPOR). Version 2020a. Berlin: Wissenschaftszentrum Berlin für Sozialforschung (WZB), 2020a. doi: 10.25522/manifesto.mpds.2020a

Volkens A., Burst T., Krause W., Lehmann P., Matthieß T., Merz N., Regel S., Weßels B., Zehnter L. The Manifesto Project Dataset - Codebook. Manifesto Project (MRG / CMP / MARPOR). Version 2020a. Berlin: Wissenschaftszentrum Berlin für Sozialforschung (WZB), 2020b. 


\title{
CONTEXTUAL MODERATION OF ANTI-IMMIGRANT MOTIVATIONS TO VOTE FOR RADICAL RIGHT PARTIES IN EUROPE V.V. Safronov
}

\author{
(vsafronov@list.ru) \\ Sociological Institute, \\ Federal Center of Theoretical and Applied Sociology, \\ Russian Academy of Sciences, \\ St. Petersburg, Russia
}

Citation: Safronov V. Contextual Moderation of Anti-Immigrant Motivations to Vote for Radical Right Parties in Europe [Kontekstnaya moderaciya antiimmigrantskih motivacij k golosovaniyu za radikal'nye pravye partii v Evrope]. Vlast' i elity [Power and Elites], 2021, 8 (2): 134-188. (In Russian)

DOI: https://doi.org/10.31119/pe.2021.8.2.6

\begin{abstract}
The article is devoted to the examination of societal conditions in European countries, contributing to the success of the radical right parties (RRP) in the parliamentary elections. Previous studies, which often lead to inconsistent results, have not paid enough attention to theoretical discussion and empirical testing of assumptions related to the influence of societal context on the relationship between anti-immigrant attitudes and electoral support for the RRP. An analysis of the European Social Survey data (ESS, recent rounds) and a range of contextual factors that distinguish European countries in terms of economic conditions, immigrant populations, crime, party systems and culture was carried out using statistical methods of two-level logistic modeling. It showed that the negative attitude of the respondents to immigration is the most important reason for their electoral support for radical nationalist parties. This influence is especially pronounced in Western countries, but it can also be found in Eastern Europe. Structural, institutional and cultural factors are only weakly related to the unequal success rates of these parties in the countries studied. The most distinct influences are found when considering party systems. The results show that right-wing radicals succeed when their electoral appeals are legitimized by a shift in the conservativenationalist direction of the main party of the right or the party system as a whole. They also manage to attract more voters when the salience of socio-cultural problems in the party system is high and with a strong polarization of party positions on these problems. A number of contextual factors are moderators of the relationship between the anti-immigrant beliefs of the respondents and the voting for the RPP. Individuals who hold these beliefs are especially willing to vote for radical parties when there are many immigrants in the country or their number
\end{abstract}


is growing rapidly. Another important condition is the advancement of society along the trajectory of post-industrial development. Anti-immigrant motivations for nationalist parties voting intensify with the rise in economic well-being, the expansion of the service sector, the strengthening of the welfare state, and with a cultural shift from anxiety toward growth.

Keywords: Radical right parties, parliamentary elections, voting, antiimmigrant beliefs, contextual societal factors, moderation effects, European Social Research (ESS Round 9). 